\title{
Numerical reconstructions of the penultimate glacial maximum Northern Hemisphere ice sheets: sensitivity to climate forcing and model parameters
}

\author{
CLAUDIA WEKERLE, ${ }^{1,2}$ FLORENCE COLLEONI, ${ }^{2}$ JENS-OVE NÄSLUND, ${ }^{3}$ \\ JENNY BRANDEFELT, ${ }^{3}$ SIMONA MASINA ${ }^{2,4}$ \\ ${ }^{1}$ Alfred-Wegener-Institut, Helmholtz Centre for Polar and Marine Research, Bremerhaven, Germany \\ ${ }^{2}$ Centro Euro-Mediterraneo sui Cambiamenti Climatici (CMCC), Bologna, Italy \\ ${ }^{3}$ Swedish Nuclear Fuel and Waste Management Company, Stockholm, Sweden \\ ${ }^{4}$ Istituto Nazionale di Geofisica e Vulcanologia, Sezione di Bologna, Italy \\ Correspondence: Claudia Wekerle <claudia.wekerle@awi.de>
}

\begin{abstract}
Numerous ice-sheet reconstructions of the last glacial cycle have been proposed, however due to limited geological evidence, reconstructing older Northern Hemisphere ice sheets remains a difficult exercise. Here we focus on the penultimate glacial maximum (PGM; $\sim 140 \mathrm{ka} B$ P) over the Northern Hemisphere. While some evidence of the PGM Eurasian ice-sheet extent were found, this is not the case for the corresponding Laurentide ice sheet. To improve the glaciological reconstructions of the PGM Northern Hemisphere ice sheets, we explore the parameter space of ice-sheet model uncertainties and carry out numerous univariate ice-sheet steady-state sensitivity simulations. We use two PGM climate simulations to force the ice-sheet model, differing in the prescribed Laurentide ice topography (small and large). The simulated Northern Hemisphere ice volume ranges from 124.7 to $152 \mathrm{~m} \mathrm{SLE}$ when using the climate accounting for a small Laurentide ice sheet, which is compatible with global sealevel reconstructions of this period $(-92$ to $-150 \mathrm{~m})$. Conversely, using the climate simulation with a Laurentide ice sheet comparable in size to that of the last glacial maximum results in too large ice volumes. Changes in basal drag provide the upper bound ice volume of our experiments, whereas changes in the distribution of ice streams provide the lower bound.
\end{abstract}

KEYWORDS: ice-sheet modelling, ice-sheet reconstruction, paleoclimate

\section{INTRODUCTION}

In the past, the Northern Hemisphere has been periodically affected by glaciations. While numerous reconstructions of the last glacial cycle global ice-sheet topography exist, only limited geological evidence of the penultimate glacial cycle or older ice topography is available. Here we focus on the reconstruction of the Northern Hemisphere ice sheets during the Marine Isotope Stage 6 (MIS 6) glacial maximum ( 140 ka BP), denoted as the penultimate glacial maximum (PGM).

For the PGM Eurasian ice sheet, an extent considerably larger than its Last Glacial Maximum (LGM; 21 ka BP) counterpart was provided by the QUEEN project (Svendsen and others, 2004). In particular, the reconstruction extends further eastwards and southwards over Siberia than during the LGM. However, the advance of the eastern part of the Eurasian ice sheet could have occurred before the PGM, as two other advances during the MIS 6 glacial cycle, at $\sim 160$ ka BP and $180 \mathrm{ka} \mathrm{BP}$, have been identified (Astakhov, 2004; Svendsen and others, 2004). While geological evidence of the extent have been retrieved, there are only a few reconstructions of the PGM Eurasian ice-sheet volume. Lambeck and others (2006) inverted observations of shoreline elevations change resulting from post-glacial isostatic rebound and obtained a PGM Eurasian ice volume of $\sim 60 \mathrm{~m} \mathrm{SLE}$ (meters sea level equivalent). Based on the extent of the PGM Eurasian ice sheet from Svendsen and others (2004), Peyaud (2006) simulated an Eurasian ice volume of $\sim 70 \mathrm{~m}$
SLE. The ICE-5G reconstruction by Peltier (2004) suggested an LGM Eurasian ice-sheet volume of $22 \mathrm{~m}$ SLE. Recently, Kleman and others (2013) analysed new evidence and simulated a value of $\sim 20 \mathrm{~m}$ SLE. In terms of global ice volume, Masson-Delmotte and others (2010) estimated that over the past million years the PGM Eurasian ice sheet only had the sixth largest global ice volume (LGM was seventh), implying that potential past glaciations, larger than the PGM glaciation, could have occurred.

In contrast to the Eurasian ice sheet, there is no geological evidence of the extent and volume of the Laurentide ice sheet older than the LGM. Moraine dating indicates that the LGM extent was the largest glaciation that occurred in North America over the past $400 \mathrm{ka}$, which suggests that traces of previous glaciations were destroyed during the LGM (Dyke and others, 2002). Naafs and others (2013) found that ice rafting episodes, produced by surges mostly through the Hudson Strait, were less pronounced during MIS 6 than during the last glaciation. Similarly, the decreased amount of ice rafted debris found north of Grand Banks and off the western Iberian margin suggest a smaller Laurentide ice sheet during the PGM than during the LGM (Hiscott and others, 2001; Abreu and others, 2003). On the contrary, ice rafted debris accumulation in the North Pacific indicates that the glaciation over Kamchatka, coastal Alaska and Siberia might have been more extensive during the PGM than during the LGM (St John and Krissek, 1999; Nürnberg and others, 2011; Barr and Solomina, 2014). 
As a matter of fact, the lack of evidence about the Laurentide ice-sheet extent at the PGM limits an accurate climate modeling for this time period. For example, Ullman and others (2014) and Beghin and others (2015) demonstrated with idealized experiments that changing the size of the North American ice sheet induces a shift in the planetary waves, thus influencing the climate over Eurasia. In a recent study, Colleoni and others (2016b) tested the impact of ice elevation over North America on the climate of the PGM. They showed that, in agreement with previous studies (e.g. Pausata and others, 2011; Ullman and others, 2014), prescribing a smaller Laurentide ice sheet yields higher temperatures and precipitation rates over the North Atlantic and northern Eurasia, and lower temperatures over East Siberia compared with setting the Laurentide ice sheet as large as during the LGM.

The large uncertainty in the volume of the PGM Eurasian and Laurentide ice sheets and the extent of the latter calls for dedicated ice-sheet modeling studies. To give a reliable estimate of the Northern Hemisphere ice-sheet geometry, we need to explore the parameter space of ice-sheet model uncertainties. This approach was followed by Marshall and others (2002) to study the dynamics of the North American ice sheet at the LGM.

The objective of the present paper is to obtain a range of reliable estimates of the PGM Northern Hemisphere ice volume by means of a 3-D thermo-mechanical ice-sheet model. To this end, the ice-sheet model is forced with the two PGM glacial-maximum climates simulated by Colleoni and others (2016b) prescribing different ice elevations over North America. Those two topographies are highly idealized, but using them in the present study allows us to investigate the sensitivity of those two PGM ice sheet reconstructions, which also bear large uncertainties in the Eurasian icesheet dimensions, to changes in model parameters. We conduct a large number of univariate steady-state sensitivity experiments, in which parameters related to surface mass balance, thermodynamics, ice-sheet geometry and solid Earth are varied. We perform steady-state simulations, since necessary boundary and forcing conditions for transient simulations are not available. In addition, we use global sea-level reconstructions to put some constraint on the simulated PGM Northern Hemisphere ice volumes. In the following sections, we first describe the ice-sheet model used in the present study as well as the design of the ice-sheet experiments. Then we analyze the ensemble of simulated Northern Hemisphere ice-sheet topographies. Finally, we discuss the various assumptions on which this study relies and draw our conclusions.

\section{METHODS}

\subsection{GRenoble Ice Shelf and Land Ice Model (GRISLI)}

To simulate the PGM Northern hemisphere ice sheets, we use the 3-D thermo-mechanical ice-sheet-ice-shelves and ice-stream model GRISLI (Ritz and others, 2001). GRISLI is able to simulate both inland ice using the Shallow Ice Approximation (SIA; Hutter, 1983), as well as ice shelves and ice streams using the Shallow Shelf Approximation (SSA; MacAyeal, 1989). GRISLI has been validated over Antarctica (Ritz and others, 2001) and applied to study the inception of the Eurasian ice-sheet growth during the Early
Weichselian period (Peyaud, 2006; Alvarez-Solas and others, 2011).

In GRISLI, potential ice stream areas are determined from bedrock topography, assuming that ice streams are located in narrow bedrock valleys. In addition, ice streams are also allowed in areas where a sufficiently thick sediment layer, determined from a map of present-day sediment thickness by Laske and Masters (1997), is present, which has to be saturated by meltwater, and where the effective pressure $N$ (balance between ice pressure and subglacial water pressure) is low. The SSA is then triggered when those criteria are fulfilled. Ice shelves are treated in GRISLI by means of the SSA. In every time step, the position of the grounding line, and therefore of ice shelves is determined with a flotation criterion, based on Archimedes' principle.

Accumulation corresponds to the mean annual total precipitation, which in this study is taken from Colleoni and others (2016b). It is totally turned into snow using a density of $917 \mathrm{~kg} \mathrm{~m}^{-3}$. Ablation is parameterized using the PositiveDegree-Day (PDD) semi-empirical method (Reeh, 1991). This method is based on an empirical relationship between the number of PDDs, computed from annual mean and July surface air temperature, and the snow and ice melting rates, which depend on the melting factors $C_{\text {snow }}$ and $C_{\text {ice, }}$ derived from observations. The number of PDDs is given by:

$$
P D D=\frac{1}{\sigma \sqrt{2 \pi}} \int_{1 \mathrm{a}} \int_{0}^{\infty} \exp \left(\frac{-\left(T-T_{\mathrm{d}}\right)^{2}}{2 \sigma^{2}}\right) d T d t
$$

where $T_{\mathrm{d}}$ is the daily temperature and $\sigma$ the standard deviation of the daily temperature. This formulation allows for positive temperatures even when the average daily temperature is below the melting point. The daily temperature $T_{\mathrm{d}}$ is reconstructed from annual mean and July temperatures, $T_{\text {Ann }}$ and $T_{\text {Jul }}$, by assuming that the annual temperature cycle follows a cosine function:

$$
T_{\mathrm{d}}(t)=T_{\text {Ann }}+\left(T_{\text {July }}-T_{\text {Ann }}\right) \cos (2 \pi t / 365) .
$$

In every time step during the simulation, climate input fields, namely initial downscaled surface air temperature $T_{0}$ and initial total precipitation $P_{0}$, are corrected for elevation changes:

$$
\begin{gathered}
T_{\text {cor }}(t)=T_{0}+\lambda\left(S(t)-S_{0}\right), \\
P_{\text {cor }}(t)=P_{0} \cdot \exp \left(\gamma \cdot\left(T_{\text {cor }}(t)-T_{0}\right)\right),
\end{gathered}
$$

where $T_{\text {cor }}$ and $P_{\text {cor }}$ are the corrected temperature and precipitation fields, respectively, $S$ is the surface elevation at time step $t, S_{0}$ is the initial surface elevation $\lambda\left({ }^{\circ} \mathrm{C} \mathrm{km}^{-1}\right)$ is the atmospheric lapse rate and $\gamma\left(\% /{ }^{\circ} \mathrm{C}^{-1}\right)$ is the precipitation correction factor. Note that the use of an exponential function in Eqn (4) is motivated by the saturation pressure of water vapor in the atmosphere (Clausius-Clapeyron relationship), which increases roughly exponentially with temperature (e.g. Charbit and others, 2002).

Geothermal heat flux (GHF) at the base of the ice sheet is prescribed, taken from a present-day distribution by Shapiro and Ritzwoller (2004). Here we assume that GHF was not significantly different during MIS 6. Calving at the ice shelf front is determined by a thickness criterion. The isostatic response in GRISLI is described by the elastic lithosphere/relaxing asthenosphere method (ELRA; Le Meur and Huybrechts, 1996). 

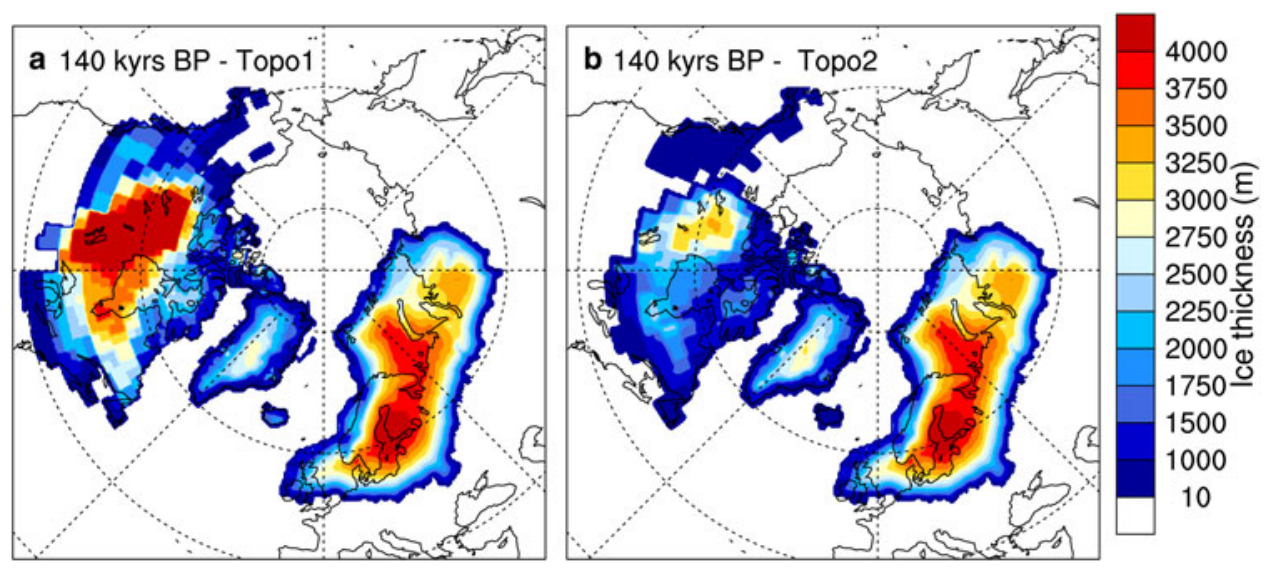

Fig. 1. PGM ice thickness ( 140 ka BP) prescribed in Colleoni and others (2016b) K140_Topo1 (a) and K140_Topo2 (b) climate simulations. The Eurasian ice sheet corresponds to the PGM reconstruction from Peyaud (2006). Since there is no evidence about the Laurentide and the Antarctic ice sheets, we use the ICE-5G ice topography (Peltier, 2004) at Last Glacial Maximum ( 21 ka BP) in K140_Topo1 and a smaller Laurentide ice topography, taken from Peltier (2004) at 13 ka BP in K140_Topo2 to equilibrate the global ice volume.

The equations governing ice flow, ice thickness and ice temperature evolution are discretized with the finite difference method. They are solved on a Cartesian grid (40 $\mathrm{km} \times 40 \mathrm{~km}$ ) corresponding to 241 grid points in both $X$ and $Y$ directions, covering the Northern Hemisphere down to $37^{\circ} \mathrm{N}$ and using a Lambert Equal Area geographical projection. In the vertical, the grid has 21 levels evenly spaced along the $z$-axis, scaled to the ice thickness, and four levels in the bedrock layer.

Two types of ice-sheet simulations, Topo1 and Topo2, were performed, differing in the initial topographies over North America (surface topography, bedrock topography and ice thickness) and prescribed climates (Section 2.2). Both topographies are constituted from the LGM Greenland ice sheet from ICE-5 G (Peltier, 2004) and from the PGM Eurasian ice sheet (Peyaud, 2006), whose elevation reaches $\sim 3500 \mathrm{~m}$ over Eurasia (Fig. 1). The extent of this PGM Eurasian ice-sheet derives from the QUEEN project (Svendsen and others, 2004). However, Topo1 and Topo2 differ in the prescribed Laurentide ice sheet. While Topo1 is constituted from the Laurentide LGM ice sheet based on ICE-5G, Topo2 is constituted from a smaller Laurentide ice sheet following Colleoni and others (2016b) to account for the uncertainties on the Laurentide ice-sheet extent during the PGM (Fig. 1).

\subsection{Climate forcing}

We use the PGM climate simulations carried out by Colleoni and others (2016b). The MIS 6 glacial maximum climate was simulated using the CESM 1.0.5, a fully coupled Atmosphere-Land-Ocean-Sea-Ice model (Gent and others, 2011). The CESM coupled model was run on a finite volume grid with an horizontal resolution of $\sim 1^{\circ}$. The atmosphere component (CAM4) has 26 vertical levels. The land model (CLM) shares the grid and horizontal resolution of the atmospheric model. The ocean model (POP2) has 60 vertical levels and is run on a grid with displaced pole over Greenland. The sea-ice model (CICE4) is fully thermodynamical and shares the grid with the ocean model. Colleoni and others (2016b) provide further details about the simulations and their analysis. The two climate simulations, namely K140_Topo1 and K140_Topo2, were carried out both using the same orbital parameters (Berger and Loutre, 1991), $\mathrm{CO}_{2}$ (Petit and others, 1999) and $\mathrm{CH}_{4}$ (Spahni and others, 2005) as for the MIS 6 glacial maximum ( 140 ka), but using the two different topographies, Topo1 and Topo2 (Fig. 1).

Each climate simulation was run for 900 model years, which is sufficiently long to reach a quasi-equilibrium state in all the model components, even if a small drift still persists in the abyssal circulation (Colleoni and others, 2016b). Dynamically, the PGM glacial topography induces a strengthening of the westerlies, a southward expansion of the sea-ice cover, and a southward shift of the AMOC convection sites compared with pre-industrial climate. These changes are in line with those simulated for the LGM (Brady and others, 2013). The reader may refer to Colleoni and others (2016b) for further details on the climate simulations. As input fields, GRISLI needs monthly surface air temperature and precipitations. These fields were averaged over the last 50 years of the climate simulations and used to force GRISLI (Fig. 2).

\subsection{Ice-sheet experiments}

Two reference ice-sheet experiments were carried out using K140_Topo1 and K140_Topo2 climate forcings (denoted by REF_Topo1 and REF_Topo2) and integrated for $450 \mathrm{ka}$. Steady-state ice volume was reached as soon as $~ 350 \mathrm{ka}$. Both reference experiments use the physical parameters as given in Table 1. The choice of reference parameter values is based on standard values found in the ice-sheet literature.

In order to investigate the sensitivity of the simulated Northern Hemisphere ice sheets to model parameters, a total of 66 univariate sensitivity experiments, summarized in Table 1, is performed. In particular, 14 model parameters were investigated, which can be assigned to five groups of experiments: impact of climate downscaling and accumulation (group A), PDD parameters (group B), parameters related to basal dragging (group C), parameters related to ice-shelf geometry (group D) and solid Earth parameters including GHF (group E). The parameter space that we chose is broad, but does not include all model parameters. However we are confident that we investigated the most sensitive parameters. All parameters were changed one by one 

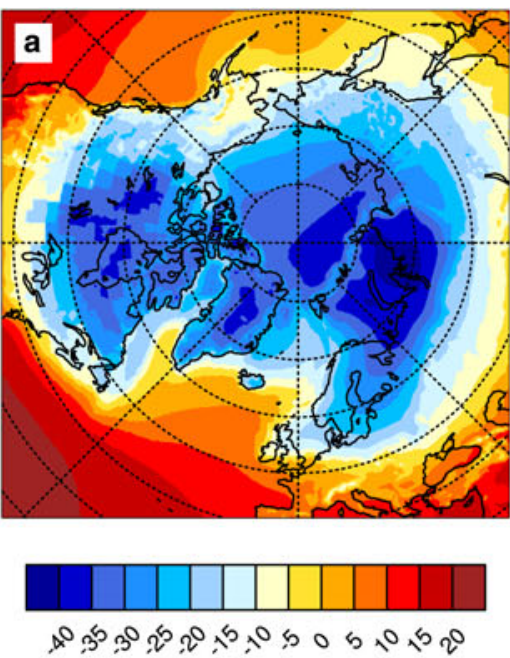

Temperature $\left({ }^{\circ} \mathrm{C}\right)$
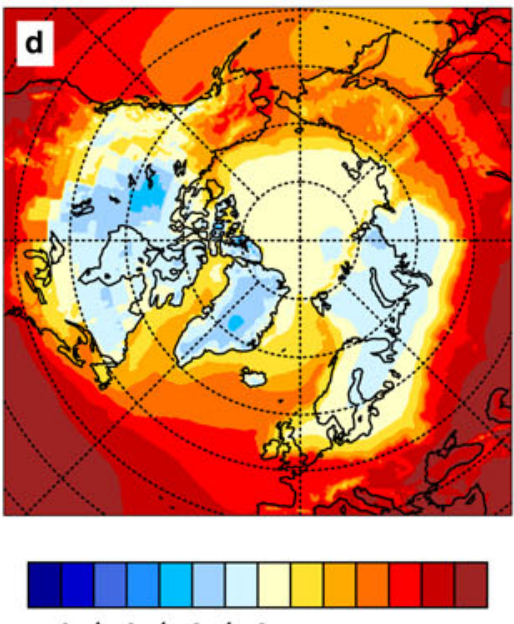

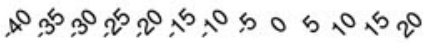

Temperature $\left({ }^{\circ} \mathrm{C}\right)$
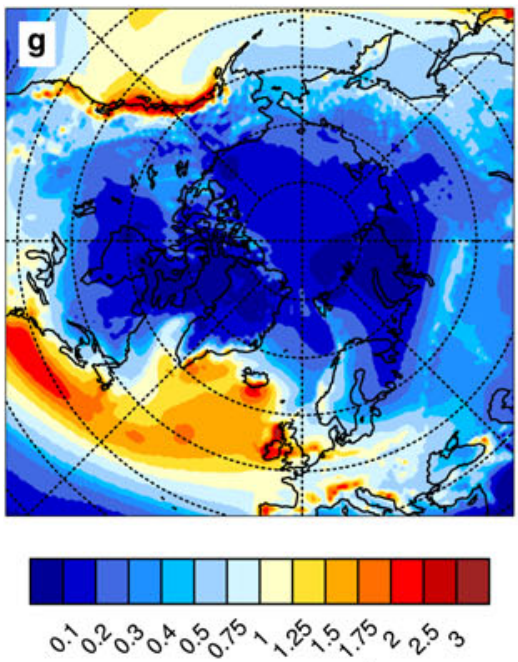

Precipitation $\left(\mathrm{m} \mathrm{a}^{-1}\right)$
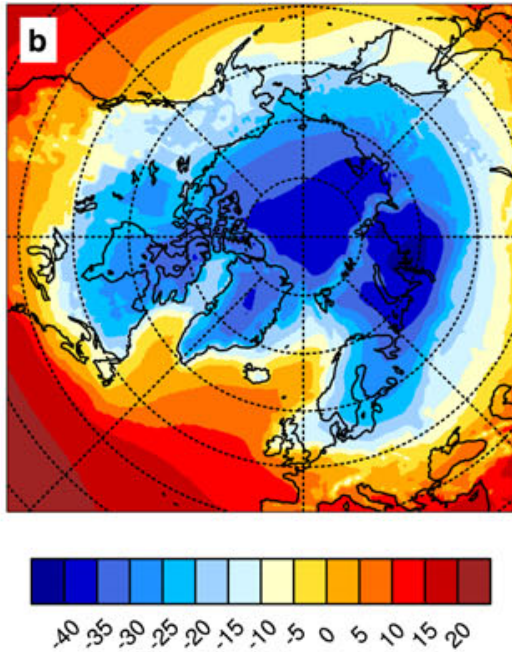

Temperature $\left({ }^{\circ} \mathrm{C}\right)$
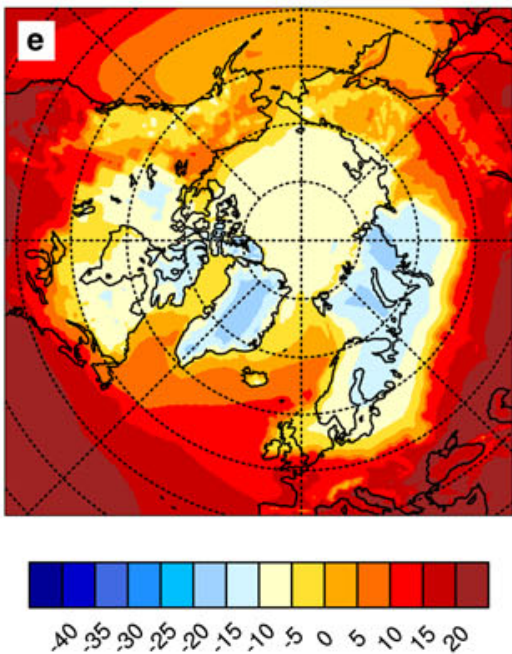

Temperature $\left({ }^{\circ} \mathrm{C}\right)$
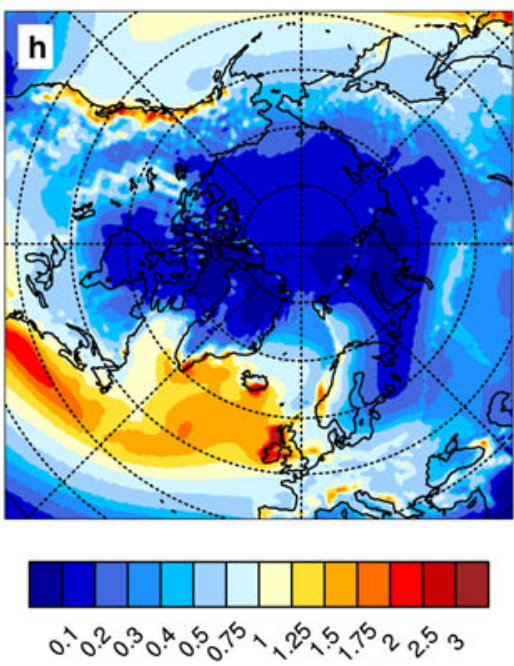

Precipitation $\left(\mathrm{m} \mathrm{a}^{-1}\right)$
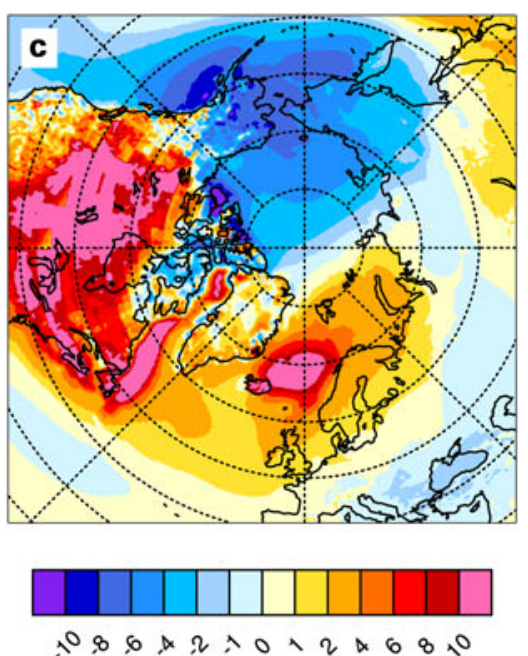

Temperature difference $\left({ }^{\circ} \mathrm{C}\right)$
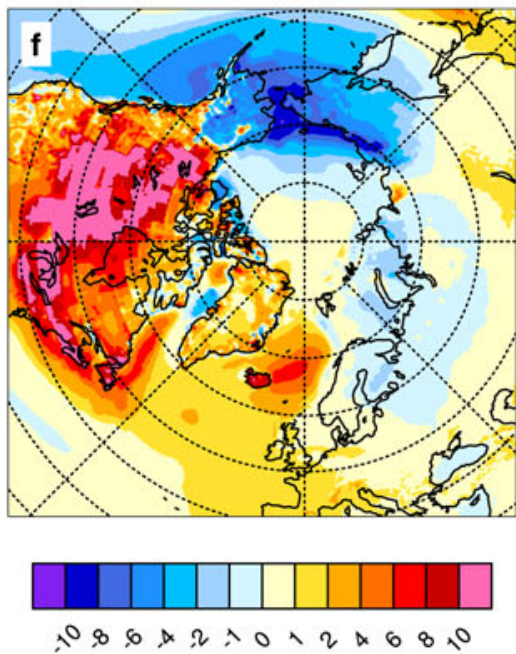

Temperature difference $\left({ }^{\circ} \mathrm{C}\right)$
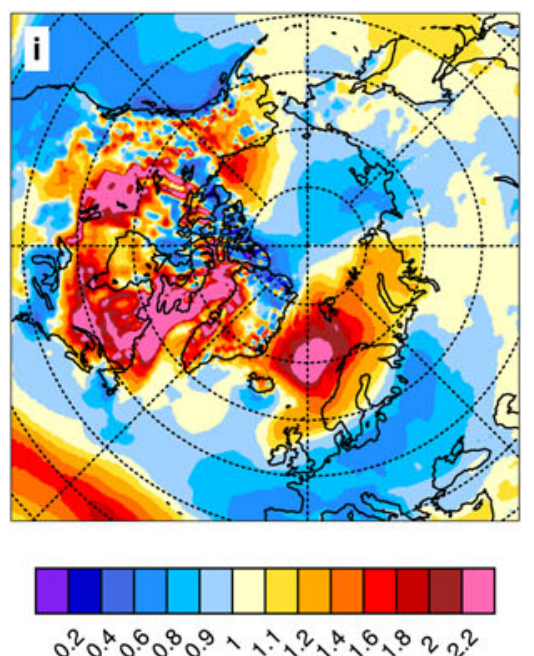

Precipitation ratio

Fig. 2. Annual mean (top) and July (middle) surface air temperature $\left({ }^{\circ} \mathrm{C}\right)$ and annual mean total precipitation ( $\mathrm{m} \mathrm{a}^{-1}$, bottom) averaged over the past 50 a of the CESM climate simulations described by Colleoni and others (2016b), interpolated and downscaled on the Northern Hemisphere $40 \mathrm{~km}$ GRISLI grid. The left and middle panels show fields for K140_Topo1 and K140_Topo2, respectively. The right panel shows the difference (for temperature, K140_Topo2 minus K140_Topo1) and ratio (for precipitation, K140_Topo2/K140_Topo1) between the two simulations. 
Table 1. Overview of reference ice-sheet experiments parameters and ice-sheet sensitivity experiments

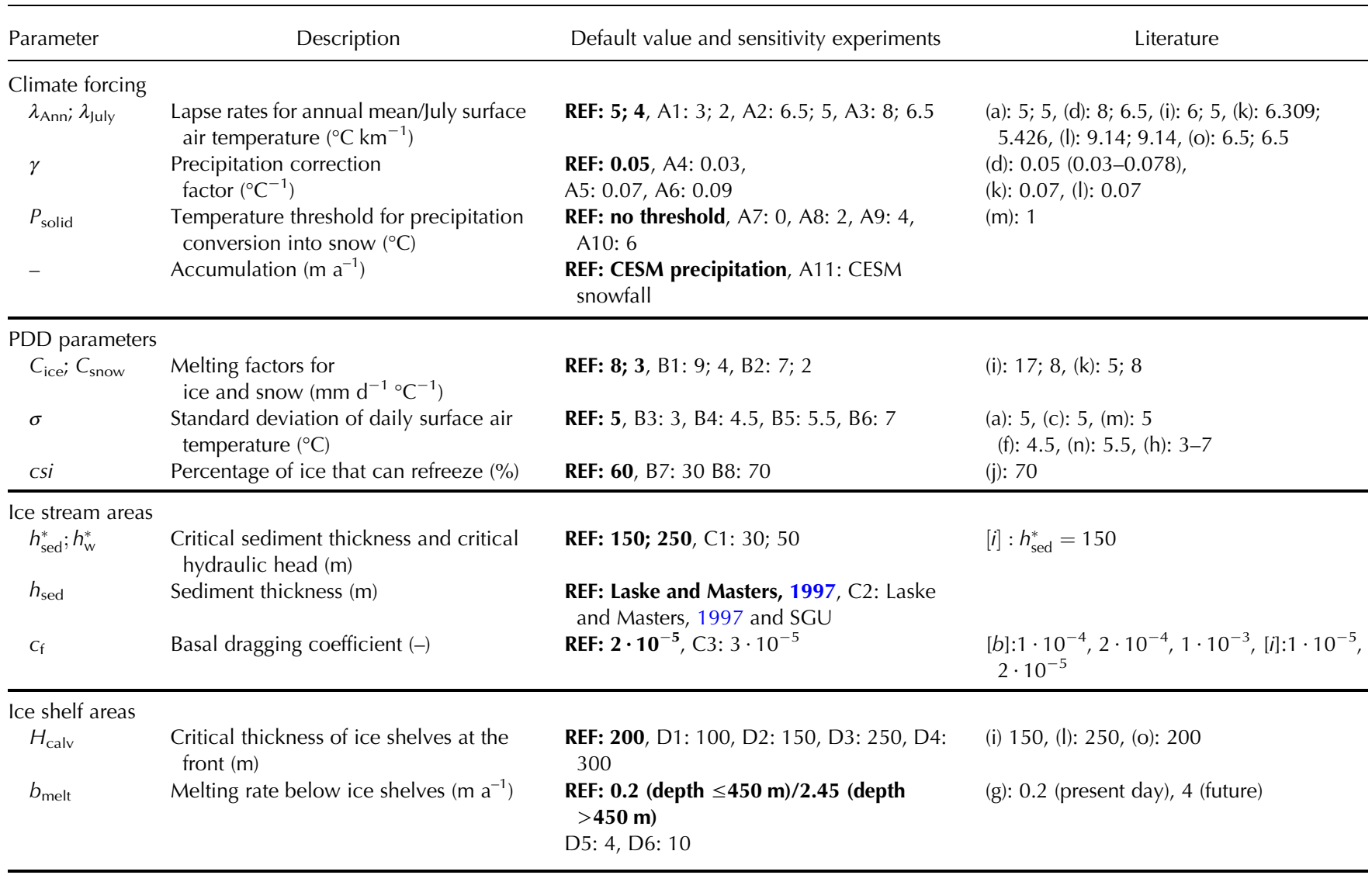

\begin{tabular}{cl}
\hline Solid earth & \\
$\tau_{\mathrm{r}}$ & Characteristic relaxation time (a) \\
$\mathrm{GHF}$ & Geothermal heat flux $\left(\mathrm{mW} \mathrm{m}^{-2}\right)$
\end{tabular}

REF: 3000, E1: 5000, E2: 10000

REF: Shapiro and Ritzwoller, 2004

E3: reduction by $10 \%$

E4: increase by $10 \%$

E5: Shapiro and Ritzwoller, 2004 and

Näslund and others, 2005

For comparison, values from literature are given. (a) Abe-Ouchi and others (2007); (b) Alvarez-Solas and others (2011);(c) Bonelli and others (2009); (d) Charbit and others (2002); (e) Charbit and others (2013); (f) Greve (2005); (g) Hellmer and others (2012); (h) Marshall and others (2002); (i) Peyaud and others (2007); (j) Pfeffer and others (1991); (k) Quiquet and others (2012); (I) Ritz and others (2001); (m) Rutt and others (2009); (n) Tarasov and Peltier (1999); (o) Vizcaino and others (2010).

while setting all other parameters to reference values. All sensitivity experiments were branched at $350 \mathrm{ka}$ from the reference simulations REF_Topo1 and REF_Topo2, which were used as initial condition for topography, ice temperature and velocities. They were forced with K140_Topo1 and K140_Topo2 climates and integrated for 100 ka, i.e. until a steady-state ice volume was reached. In the following paragraphs, we describe in detail the settings of the experiments, also reported in Table 1.

\subsubsection{Climate correction during run-time}

As a first step, we investigate parameters related to climate forcing. In every time step during the simulation, climate input fields are corrected for elevation changes according to Eqns (3) and (4) by means of an atmospheric lapse rate $(\lambda)$ and a precipitation correction factor $(\gamma)$. Typical values of $\lambda$ for paleoclimate studies conducted on the Northern Hemisphere range from 5 to $8^{\circ} \mathrm{C} \mathrm{km}^{-1}$ (e.g. Abe-Ouchi and others, 2007; Alvarez-Solas and others, 2011). We set our reference values to $5^{\circ} \mathrm{C} \mathrm{km}^{-1}$ (mean annual, $\lambda_{\text {Ann }}$ ) and $4{ }^{\circ} \mathrm{C} \mathrm{km}^{-1}$ (July, $\lambda_{\text {Jul }}$ ) following Bonelli and others (2009), and for our sensitivity experiments, we choose lapse rates of $\lambda_{\mathrm{Ann}}=3^{\circ} \mathrm{C} \mathrm{km}^{-1} ; \lambda_{\text {Jul }}=2^{\circ} \mathrm{C} \mathrm{km}^{-1}$ (experiment A1), $\lambda_{\text {Ann }}=6.5^{\circ} \mathrm{C} \mathrm{km}^{-1} ; \lambda_{\text {Jul }}=5^{\circ} \mathrm{C} \mathrm{km}^{-1}$ (experiment A2) and $\lambda_{\mathrm{Ann}}=8^{\circ} \mathrm{C} \mathrm{km}^{-1} ; \lambda_{\text {Jul }}=6.5^{\circ} \mathrm{C} \mathrm{km}^{-1}$ (experiment $\mathrm{A} 3$ ). For the precipitation correction factor $\gamma$, we perform experiments with $\gamma=0.03^{\circ} \mathrm{C} \mathrm{km}^{-1}, \gamma=0.07^{\circ} \mathrm{C} \mathrm{km}^{-1}$ and $\gamma=$ $0.09^{\circ} \mathrm{C} \mathrm{km}^{-1}$ covering approximately the range tested by Charbit and others (2002) in their study of Northern Hemisphere ice sheets during the last deglaciation (experiments A4, A5 and A6, respectively). We adopt a value of $0.05^{\circ} \mathrm{C}^{-1}$ in the reference experiments, following Charbit and others (2002).

\subsubsection{Accumulation}

In our reference simulations, all total precipitation is turned into snow with a density of $917 \mathrm{~kg} \mathrm{~m}^{-3}$. For the sensitivity experiments, we adopt another approach, which consists in scaling the total precipitation (Eqn (4)) with the length of winter calculated as fraction of days per year below a 
certain temperature threshold $P_{\text {solid }}\left({ }^{\circ} \mathrm{C}\right)$, denoted by $F T$ :

$$
P_{\text {cor }}(t)=P_{0} \cdot \exp \left(\gamma \cdot\left(T_{\text {cor }}(t)-T_{0}\right)\right) \cdot F T \text {. }
$$

The impact of setting a temperature threshold according to Eqn (5) is investigated in a set of experiments with $P_{\text {solid }}$ ranging from 0 to $6^{\circ} \mathrm{C}$ (experiments $\left.\mathrm{A} 7-\mathrm{A} 10\right)$ ). As a further sensitivity test to the formulation of the precipitation forcing conditions, an experiment is performed in which we instead use the snowfall field from the two PGM climate simulations (experiment A11).

\subsubsection{PDD parameters}

We use the PDD method (Reeh, 1991) to calculate ablation, which depends on:

(1) Melting of snow and ice: $C_{\text {snow }}$ is set to $3 \mathrm{~mm} \mathrm{~d}^{-1}{ }^{\circ} \mathrm{C}^{-1}$ and $C_{\text {ice }}$ to $8 \mathrm{~mm} \mathrm{~d}^{-1}{ }^{\circ} \mathrm{C}^{-1}$ in our reference simulations, $4 \mathrm{~mm} \mathrm{~d}^{-1}{ }^{\circ} \mathrm{C}^{-1}$ and $9 \mathrm{~mm} \mathrm{~d}^{-1}{ }^{\circ} \mathrm{C}^{-1}$, respectively, in experiment B1, motivated by the fact that some ice-sheet modeling studies use higher values (e.g. Peyaud and others, 2007; Quiquet and others, 2012), and $2 \mathrm{~mm} \mathrm{~d}^{-1}$ ${ }^{\circ} \mathrm{C}^{-1}$ and $7 \mathrm{~mm} \mathrm{~d}^{-1}{ }^{\circ} \mathrm{C}^{-1}$, respectively, in experiment $\mathrm{B} 2$.

(2) The standard deviation of daily temperature, $\sigma$, is set to $5^{\circ} \mathrm{C}$ in the reference simulation (e.g. Bonelli and others, 2009), while we test values ranging from 3 to $7^{\circ} \mathrm{C}$ (experiments B3-B6; Table 1) corresponding to the values Marshall and others (2002) tested in their study of the Laurentide ice sheet.

(3) The amount of refreezing of ice-sheet surface meltwater, Csi, is set to $60 \%$ (Reeh, 1991). We test values of $30 \%$ in experiment B7 in order to investigate the impact of a rather small amount of refreezing, and $70 \%$ in experiment B8 as suggested by Pfeffer and others (1991).

Note that the PDD parameters we choose for the reference run are the standard parameters from Reeh (1991), commonly used in ice-sheet models (e.g. Abe-Ouchi and others, 2007; Bonelli and others, 2009; Rutt and others, 2009).

\subsubsection{Fast flowing areas related parameters}

Ice streams play an important role for the overall dynamics and shape of ice sheets. Two thresholds are of particular importance for the activation of ice streams in GRISLI: The hydraulic head, determined by a Darcy-type flow law, has to exceed $h_{\mathrm{w}}^{*}=250 \mathrm{~m}$ (critical hydraulic head) and the sediment thickness, taken from a map of Laske and Masters (1997) (Fig. 3a), has to exceed $h_{\text {sed }}^{*}=150 \mathrm{~m}$ (critical sediment thickness). Note that both thresholds, $h_{\mathrm{sed}}^{*}$ and $h_{\mathrm{w}}^{*}$ are closely connected to each other. These assumptions are in agreement with Clark and others (1996), who showed that a soft bed, i.e. wet, deformable till or sediment, is closely related to enhanced ice flow. However, no direct evidence constraining these values exists; this is why the uncertainty in the formulation and associated parameter values is large. To test the impact of the imposed thresholds, we conduct an experiment with smaller values $\left(h_{\mathrm{sed}}^{*}=30 \mathrm{~m}\right.$ and $h_{\mathrm{w}}^{*}=50 \mathrm{~m}$, experiment C1). Another experiment is performed that tests the impact of resolution of the sediment thickness dataset (experiment C2). Thus, a high-resolution dataset of sediment thickness covering Sweden from the Swedish Geological Survey (SGU) is merged with the global dataset from Laske and Masters (1997), and used as input map in GRISLI.

In GRISLI, the basal drag below ice stream regions, $\tau_{\mathrm{b}}$, is proportional to basal velocitiy $\overline{\mathbf{u}}$ :

$$
\tau_{\mathbf{b}}=-C_{\mathrm{f}} N \overline{\mathbf{u}},
$$

where $c_{\mathrm{f}}$ is the basal drag coefficient and $N$ the effective pressure. In the work of Peyaud (2006), $c_{\mathrm{f}}$ is set to $1 \cdot 10^{-5}$ and $2 \cdot 10^{-5}$. Alvarez-Solas and others (2011) chose larger values $\left(1 \cdot 10^{-4}, 2 \cdot 10^{-4}, 1 \cdot 10^{-3}\right)$ in order to trigger
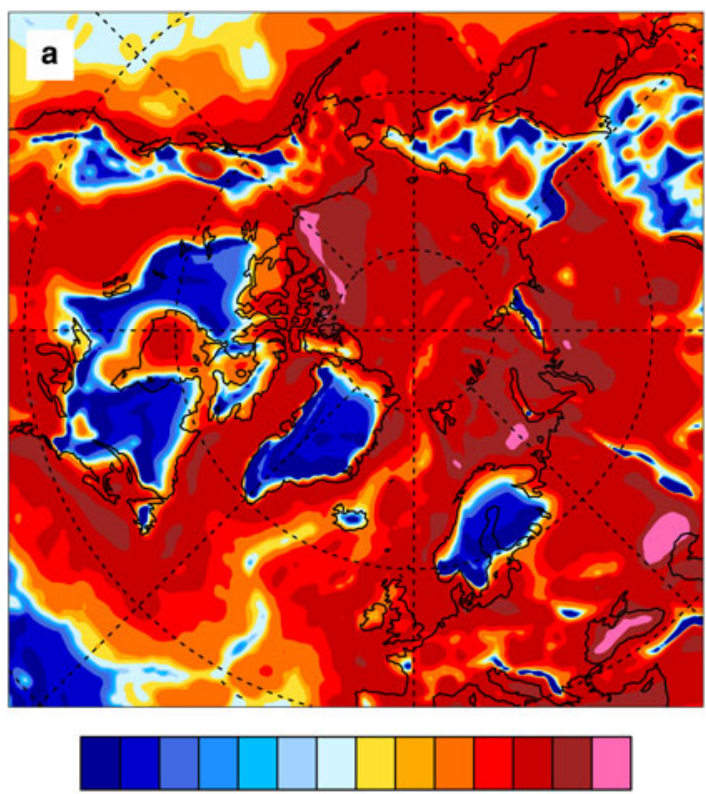

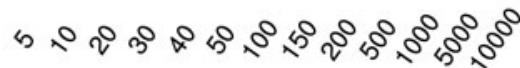
Sediment thickness $(\mathrm{m})$

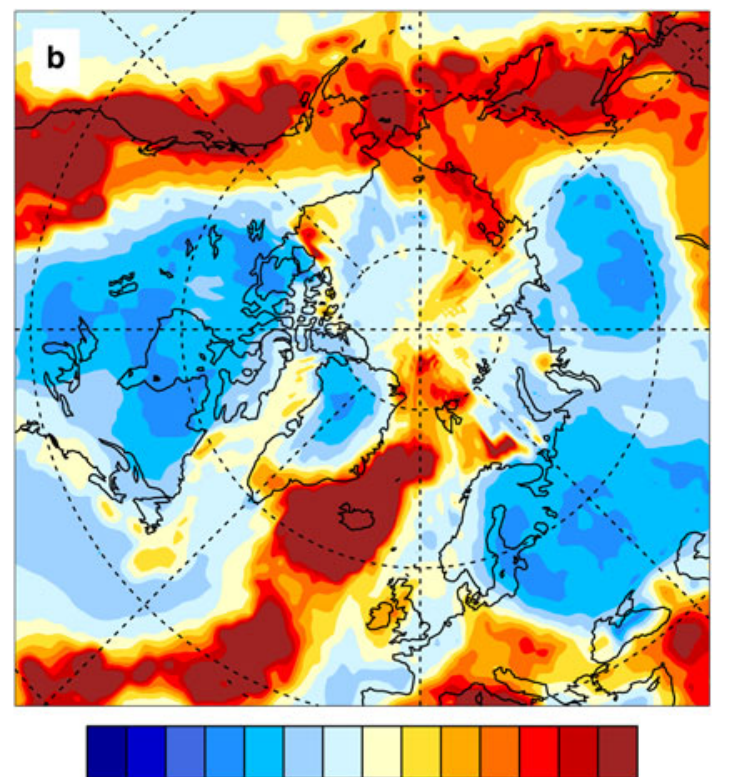

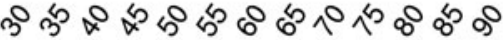
GHF $\left(\mathrm{mW} \mathrm{m}^{-2}\right)$

Fig. 3. Input maps used in GRISLI: (a) Sediment thickness from Laske and Masters (1997) and (b) GHF ( $\mathrm{mW} \mathrm{m}^{-2}$ ) from Shapiro and Ritzwoller (2004). Datasets were interpolated on the Northern Hemisphere $40 \mathrm{~km}$ GRISLI grid. 
Heinrich events, which are characterized by ice-sheet instabilities. In our reference experiments, $c_{f}$ is set to 2 . $10^{-5}$. As we do not aim to simulate very unstable ice-sheet behavior as Alvarez-Solas and others (2011), we choose to investigate the effect of a moderately larger value of $c_{\mathrm{f}}=$ $3 \cdot 10^{-5}$ in experiment $\mathrm{C} 3$.

\subsubsection{Ice-shelf geometry}

The ice-shelf geometry is affected by calving and by basal melting due to oceanic heat fluxes. Calving of ice shelves is simulated with a thickness criterion. As soon as the ice thickness at the front reaches a certain threshold $H_{\text {calv }}$ and the upstream ice fluxes are not enough to sustain the dynamical conditions at the front, the node is 'cut off'. In the literature, this threshold ranges from 150 to $250 \mathrm{~m}$, mostly based on observations of Antarctic ice shelves (Ritz and others, 2001; Peyaud and others, 2007; Vizcaino and others, 2010). Therefore, in the reference experiment, $H_{\text {calv }}$ is set to $200 \mathrm{~m}$. Sensitivity experiments test values ranging from 100 to $300 \mathrm{~m}$ (experiments D1-D4).

Basal melting below the ice shelves is strongly affected by the large-scale oceanic circulation (e.g. Hellmer and others, 2012). In our reference model setup, we use a simplified approach, in which the oceanic basal melting rate $b_{\text {melt }}$ depends on depth and is set to $0.2 \mathrm{~m} \mathrm{a}^{-1}$ above $450 \mathrm{~m}$ and to $2.45 \mathrm{~m} \mathrm{a}^{-1}$ below $450 \mathrm{~m}$ depth, similar to Peyaud and others (2007). This is in agreement with observations showing that below the halocline, ocean temperature rises until about 500 to 1000 meter depth, which would lead to high basal melting values. In our sensitivity experiments, we do not impose any depth limit and we prescribe high uniform basal melt values, $b_{\text {melt }}=4 \mathrm{~m} \mathrm{a}^{-1}$ and $b_{\text {melt }}=10 \mathrm{~m} \mathrm{a}^{-1}$ (experiments D5 and D6).

\subsubsection{Solid earth: Isostasy and GHFs}

In GRISLI, we apply the ELRA method to compute isostasy, treating the lithosphere/asthenosphere system with a viscoelastic rheology which depends on time (LeMeur and Huybrechts, 1996). The response time of the asthenosphere to changes in surface load is given by the characteristic relaxation time $\tau_{\mathrm{r}}$, set to $3000 \mathrm{a}$ in the reference simulations following Turcotte and Schubert (2002). In Abe-Ouchi and others (2007) and Bonelli and others (2009) $\tau_{\mathrm{r}}$ is set to $5000 \mathrm{a}$. Therefore, as larger values for $\tau_{\mathrm{r}}$ are commonly used, we test values of $5000 \mathrm{a}$ and $10000 \mathrm{a}$ (experiments E1 and E2).

In our simulations we use a heterogeneous present-day GHF reconstructed by Shapiro and Ritzwoller (2004) with a horizontal resolution of $1^{\circ}$ (Fig. 3b). Here we assume that GHF was not significantly different during the MIS6. Other ice-sheet modeling studies apply a constant value for the whole model domain, ranging from $42 \mathrm{~mW} \mathrm{~m}^{-2}$ (Ritz and others, 2001) to $55 \mathrm{~mW} \mathrm{~m}^{-2}$ (Abe-Ouchi and others, 2007). In order to investigate the impact of changes in GHF, the GHF values from Shapiro and Ritzwoller (2004) are uniformly reduced by $10 \%$ (experiment E3) and uniformly increased by $10 \%$ (experiment $\mathrm{E} 4$ ). In experiment E5, a more accurate, high-resolution dataset of GHF covering Sweden and Finland from Näslund and others (2005) is merged with the Shapiro and Ritzwoller (2004) dataset in order to obtain a more refined GHF distribution over Scandinavia. In comparison, the average value over Sweden and Finland in Shapiro and Ritzwoller (2004) is $\sim 8 \%$ higher relative to Näslund and others (2005).

\section{RESULTS}

In the first part of this section we focus on the PGM reference ice-sheet simulation REF_Topo1 carried out using the standard set of model parameters reported in Table 1. The second part explores the impact of climate forcing on the simulated ice sheets dimensions. In the third part we investigate the impact of each parameter category described in Section 2.3 on the simulated ice-sheet geometry (Table 1). For convenience, ice volume is converted into meter Sea-Level Equivalent (m SLE), calculated as:

$$
h_{\mathrm{SLE}}=\frac{\rho_{\text {ice }}}{\rho_{\mathrm{w}} \cdot A_{\text {oce }}} V_{\text {ice }},
$$

where $A_{\text {oce }}$ is an estimate of the global present-day ocean area $\left(3.62 \times 10^{8} \mathrm{~km}^{2}\right)$ and $V_{\text {ice }}$ is the simulated ice-sheet volume. $\rho_{\text {ice }}$ is the ice density set to $917 \mathrm{~kg} \mathrm{~m}^{-3}$ and $\rho_{\mathrm{w}}$ is the sea water density set to $1028 \mathrm{~kg} \mathrm{~m}^{-3}$.

\subsection{PGM reference simulation: REF_Topo1}

The first observation is that under K140_Topo1 climate forcing, both the Laurentide and the Eurasian ice sheet remain stable. During the $450 \mathrm{ka}$ of the simulation, the volume of the Eurasian ice sheet decreases from $~ 70 \mathrm{~m} \mathrm{SLE}$ for the initial state (Peyaud, 2006) to $52 \mathrm{~m} \mathrm{SLE}$. The difference between the prescribed initial and simulated final ice-sheet volume is due to differences in the climate forcing used to generate those two Eurasian ice sheets. The climate forcing used by Peyaud (2006) was based on a climate simulation of the Early Weichselian glaciation ( 90 ka BP; Krinner and others 2004) and was modified to reconstruct the PGM Eurasian extent in agreement with Svendsen and others (2004). This forcing differs from the climates used in the present study that used the Eurasian ice-sheet topography from Peyaud (2006) and set the orbital and GHG values to the PGM. Those discrepancies with Krinner and others (2004) induce changes in the large-scale circulation, leading to substantial differences in the precipitation and surface air temperature patterns over Eurasia and Siberia. The simulated Laurentide ice volume, however, increases slightly from initially $79.8 \mathrm{~m}$ SLE (ICE-5 G reconstruction; Peltier 2004) to $83.6 \mathrm{~m} \mathrm{SLE}$ at the end of the simulation.

We now examine the final simulated ice thickness distribution over the Northern Hemisphere (Fig. 4a). Compared with the initial ice distribution, the largest differences over Eurasia are found in the south-west part and in the Barents Sea (Fig. 4d). Over eastern Siberia and Beringia, an ice cap grows in REF_Topo1, while this area was ice free in the initial topography. This will be further discussed in the next section. Over North America, the ice sheet thickens over the Hudson Bay area, whereas mass is lost over the central part, indicating an eastward shift of the main ice-sheet dome.

The Eurasian ice sheet in experiment REF_Topo1 does not expand beyond the initial ice-sheet margins (magenta outlines; Fig. 4a). Likewise, the extent of the simulated North American ice sheets does not exceed the extent of the initial prescribed topography. This is because the $0^{\circ} \mathrm{C}$ summer isotherm reaches the southward margins of both ice sheets, inhibiting their southward propagation (Fig. $2 \mathrm{~d}$ ).

Most parts of the simulated ice-sheet base exhibit temperatures above the freezing point (Fig. 5d). Proxy-based indications of basal conditions for the MIS 6 glacial maximum are not available, but, for the LGM Eurasian and 

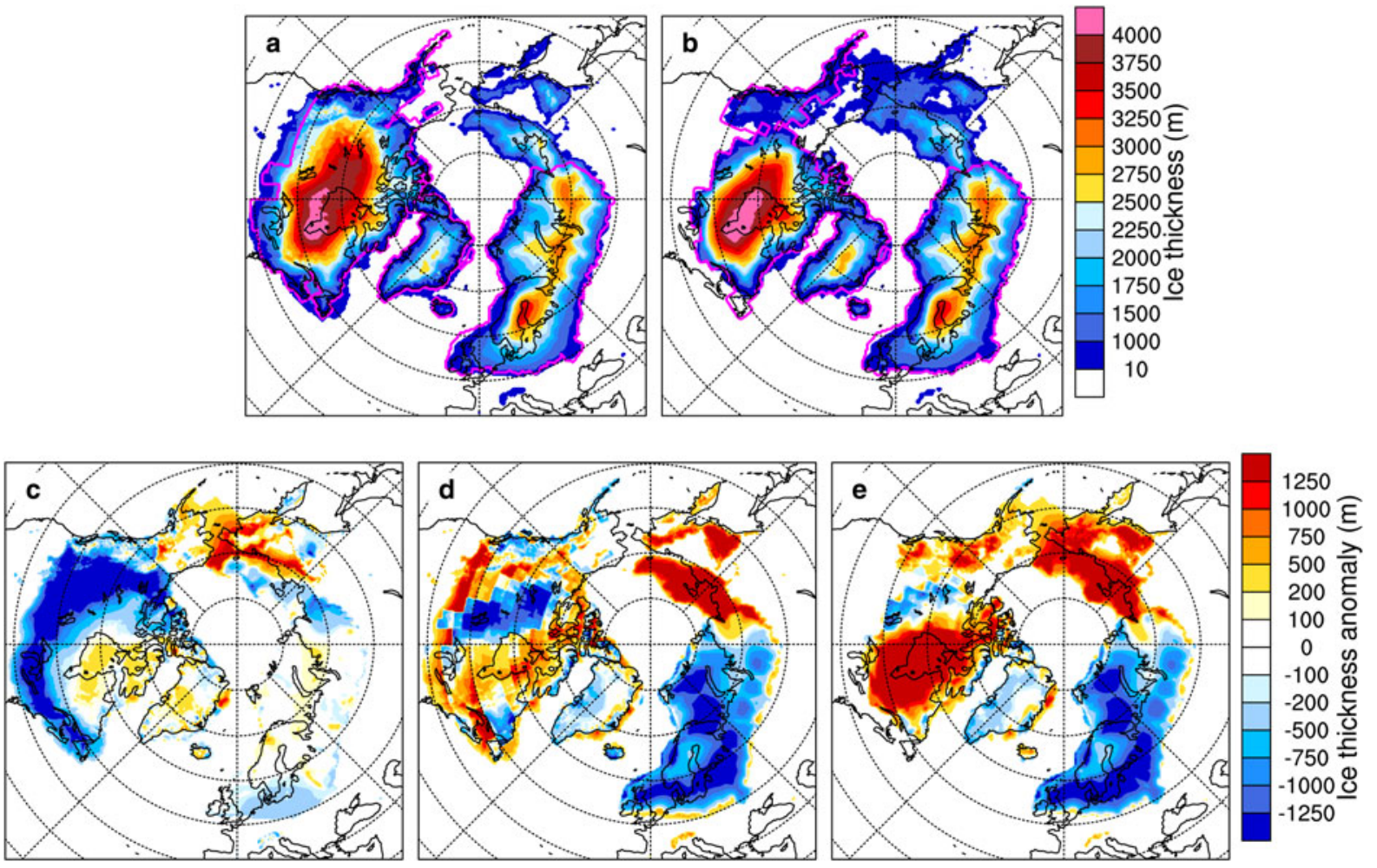

Fig. 4. Simulated final ice thickness for reference simulations REF_Topo1 (a) and REF_Topo2 (b) and differences in ice thickness: REF_Topo2 minus REF_Topo1 (c), REF_Topo1 minus initial ice thickness as shown in Fig. 1a (d) and REF_Topo2 minus initial ice thickness as shown in Fig. 1b (e). The magenta outlines in (a) and (b) indicate the extent of the prescribed ice sheets for Topo1 and Topo2 (Fig. 1) used as initial conditions.

Laurentide ice sheets, Kleman and Hattestrand (1999) inferred the distribution of frozen- and thawed-bed conditions from the occurrence of ribbed moraines in the present-day landscape. Their study shows that large parts of northern Scandinavia must have been characterized by frozen-bed conditions during the last glacial cycle, as well as the northern part of the Laurentide ice sheet including the Canadian Arctic Archipelago. Over western Finland, our simulated basal temperature in REF_Topo1 agrees with the LGM reconstruction from Kleman and Hattestrand (1999), whereas most of the ice-sheet base over Scandinavia remains above the freezing point (Fig. 5d). However, since the PGM Eurasian ice sheet is substantially larger and thicker than its LGM counterpart, the comparison here is only indicative.

Over the Canadian Arctic Archipelago and south of Hudson Bay, the simulated ice-sheet base is frozen, yet the area with frozen-bed conditions is not as extensive as described by Kleman and Hattestrand (1999). This could result from an overestimation of the Laurentide ice thickness, already large in the prescribed initial topography. In fact, to avoid unrealistic atmospheric circulation changes in the last LGM inter-comparison exercise of the PMIP3 project, the LGM ice elevation was lowered over North America, departing from Peltier (2004) ICE-5 G reconstructions (AbeOuchi and others, 2015).

\subsection{Impact of climate forcing: REF_Topo2}

Colleoni and others (2016b) showed that changes in Laurentide ice-sheet topography induce a shift in planetary waves, which affects the distribution of temperature and precipitation over the Northern Hemisphere high latitudes. In particular, in K140_Topo2 the strongest response occurs over North America, as a result of the lower elevation and smaller ice extent compared with K140_Topo1, and over the Nordic Seas, where air temperature increases up to $10^{\circ} \mathrm{C}$ and precipitation doubles compared with K140_Topo1 due to a positive geopotential height anomaly related to the shift in planetary waves (Fig. 2). In contrast, over Beringia and eastern Siberia mean annual surface air temperature decreases by up to $6^{\circ} \mathrm{C}$ in K140_Topo 2 compared with K140_Topo1, and mean July surface air temperature decreases even more as a result of the shift in planetary waves inducing a negative geopotential height anomaly over this area. For similar reasons, in the Laptev Sea, precipitation is reduced by up to $30 \%$ in K140_Topo 2 compared with K140_Topo1, while over the southern part of Eurasia, precipitation decreases as a result of the southward shift of the jet stream associated with elevation changes over North America. The reader may refer to Colleoni and others (2016b) for a more complete analysis of those two climate simulations.

Although there is a strong difference between those two climate forcings, it only has a moderate impact on the Eurasian ice-sheet topography. In fact, the simulated final REF_Topo2 Eurasian ice volume is $\sim 2 \mathrm{~m}$ SLE lower than in REF_Topo1 (Fig. 6). This difference in ice volume is mostly due to a thinning of the ice sheet in the southwestern part by up to $500 \mathrm{~m}$ in REF_Topo2 (Fig. 4c) as a result of the small summer warming occurring over this area, which is not compensated for by the large reduction in precipitation simulated over the same area. While the final simulated REF_Topo2 Laurentide ice volume is larger than its initial value (Fig. 4e), the difference in both volume and extent between Topo1 and Topo2 is preserved throughout the 

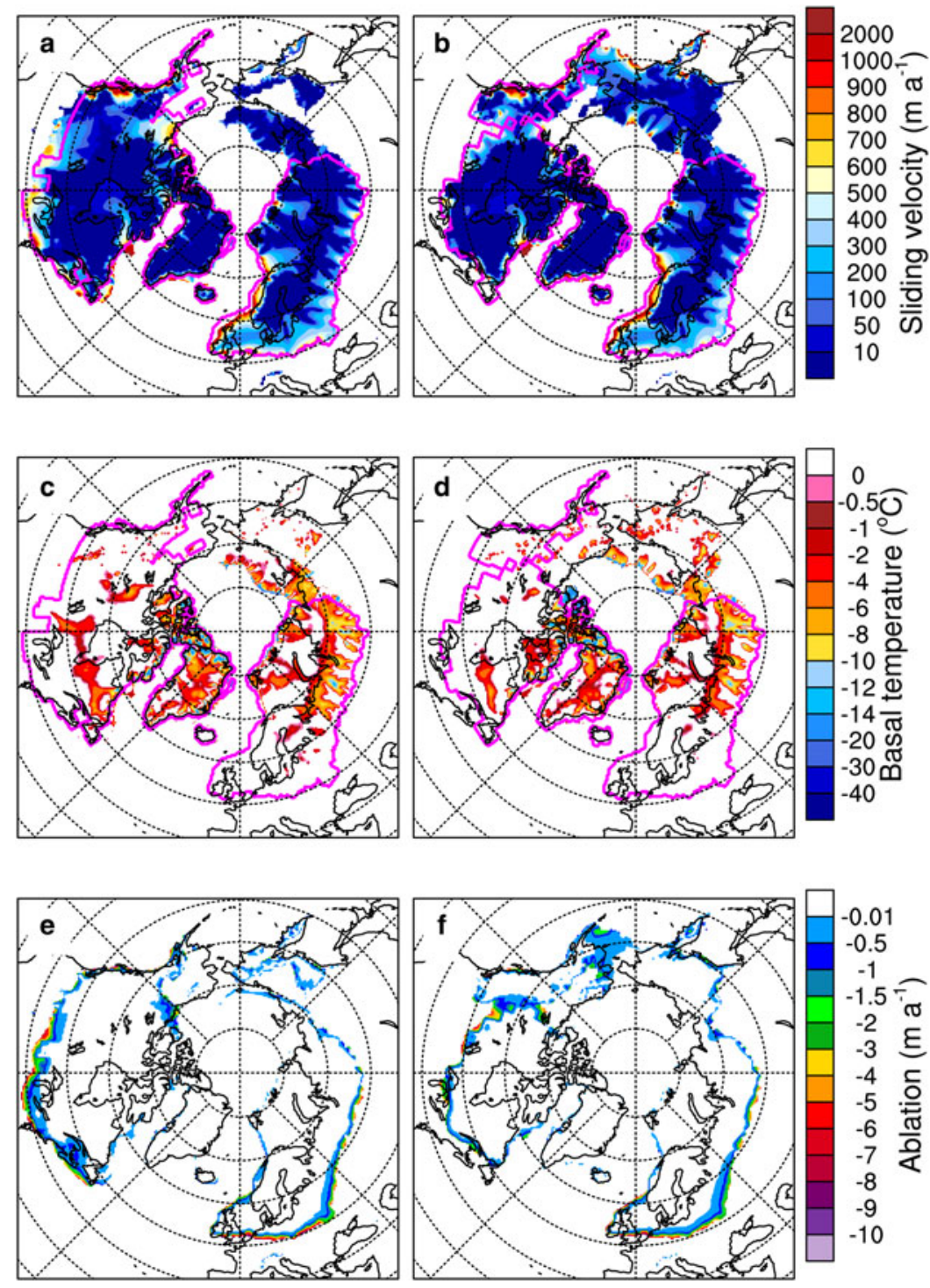

Fig. 5. Sliding velocity in $\mathrm{m} \mathrm{a}^{-1}(\mathrm{a}, \mathrm{b})$, basal temperature relative to the pressure melting point in ${ }^{\circ} \mathrm{C}(\mathrm{c}, \mathrm{d})$ and ablation in $\mathrm{m} \mathrm{a}^{-1}(\mathrm{e}, \mathrm{f})$ of reference simulations REF_Topo1 (left column) and REF_Topo2 (right column) at the end of the simulations. The magenta outlines indicate the extent of the prescribed ice sheets for Topo1 and Topo2 (Fig. 1) used as initial conditions.

REF_Topo2 simulation (Fig. 4c). The REF_Topo2 Laurentide ice sheet remains less extended in the southern part than in REF_Topo1 but thickens by 500 m over the Hudson Bay. The final Laurentide ice volume of $59.2 \mathrm{~m} \mathrm{SLE}$ is $24.4 \mathrm{~m}$ SLE less than in the case of REF_Topo1 (Table 2). In the following, we review some observational evidence to strengthen our analysis and provide some hints to constrain the PGM Northern Hemisphere ice topography.

According to Naafs and others (2013) and Obrochta and others (2014), the PGM Laurentide ice sheet may have been smaller than during the LGM. The authors deduce this from the fact that ice rafting events in the North Atlantic, which originate from the Hudson area, were much reduced during MIS 6. Similarly, Abreu and others (2003), investigating ice-rafted debris off the western Iberian margin, conclude that ice-rafting episodes were far less pronounced during MIS 6 than during the end of the last glacial cycle. Hiscott and others (2001) analyzed sediment cores from the area north of Grand Banks and found only minor ice rafting events during MIS 6 . The above described evidence clearly favor a Laurentide topography as in simulation REF_Topo2. In particular, the REF_Topo2
Laurentide ice sheet does not cover the Newfoundland area (Fig. 4b). This results from the simulated warmer climate conditions, especially during summer over Newfoundland, combined with a reduction in simulated precipitation in K140_Topo2 compared with K140_Topo1 (Fig. 2). Furthermore, the velocities of the ice stream flowing in the Hudson Strait and those flowing along the Labrador Sea coast are much lower in REF_Topo2 than in REF_Topo1 (Fig. 5a, b). This indicates that the PGM simulated climate inhibits the ice growth over this area and therefore the ice sheet is shifted slightly more inland in REF_Topo2 than in REF_Topo1. In fact, the main Laurentide ice-sheet dome is centered over the Hudson Bay in REF_Topo2, while it is slightly shifted southward in REF_Topo1 (Fig. 4a, b). Furthermore, the main Laurentide ice-sheet dome grows along a northwest-southeast axis in REF_Topo2, while in REF_Topo1, the ice-sheet growth is more zonal.

In East Siberia, observations indicate that this area was extensively glaciated during MIS 6, while this was not the case during the LGM. Barr and Solomina (2014) reported that during MIS 6, the glaciation over the Kamchatka peninsula was more extensive and likely covered the entire peninsula. 

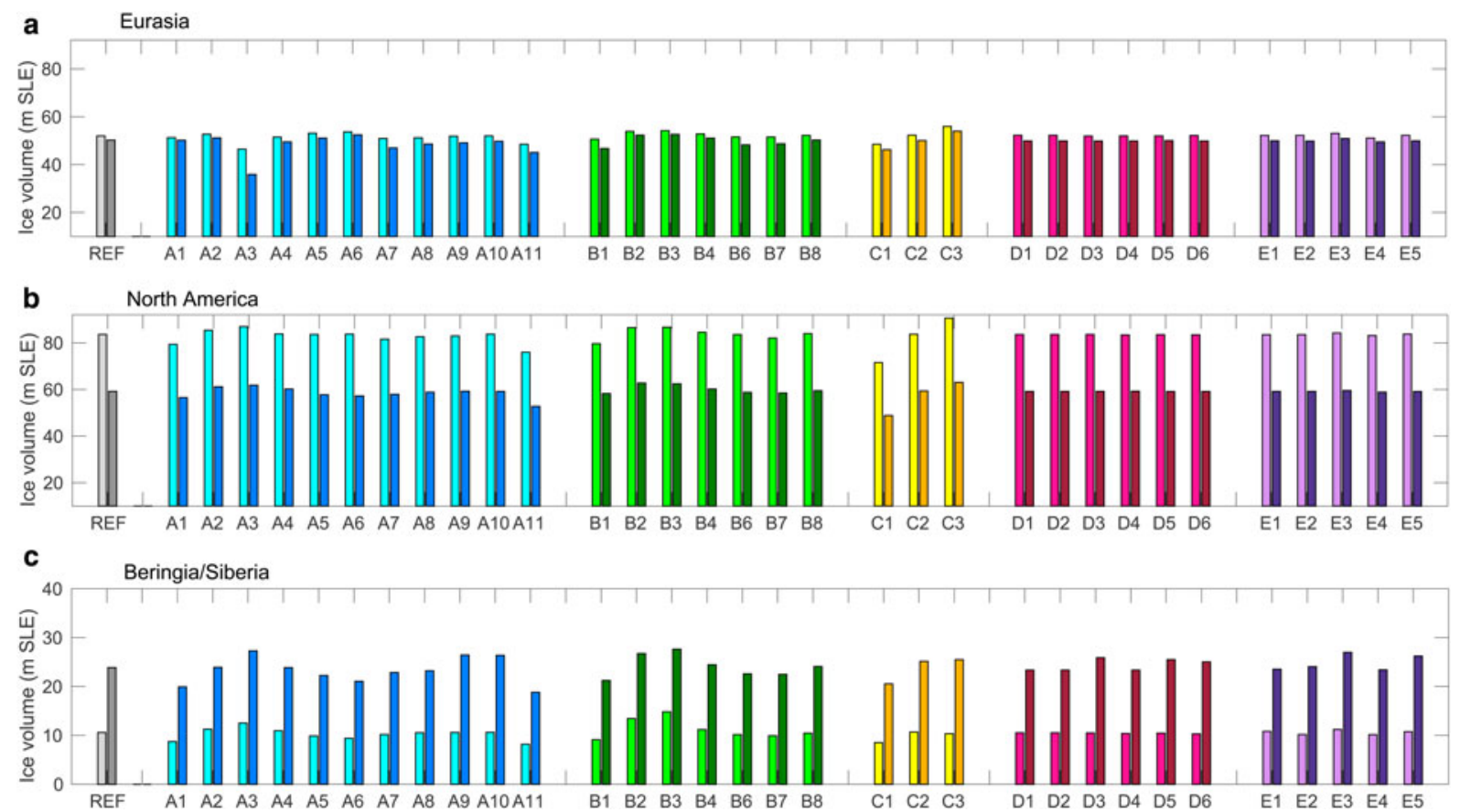

Fig. 6. Ice volume (m SLE) of the Eurasian (a), North American (b) and Beringia/Siberian ice sheets (c) for all preformed experiments using K140_Topo1 forcing (light colors) and K140_Topo2 forcing (dark colors) at the end of the simulations.

Moreover, ice-rafted debris was found in the North Pacific originating from coastal Alaska, coastal Siberia and the Kamchatka peninsula (St John and Krissek, 1999; Nürnberg and others, 2011). According to Nürnberg and others (2011), ice-rafted debris accumulation in the Okhotsk Sea was significantly higher during the PGM compared with the LGM. Our simulations show that the glaciated area over East Siberia in REF_Topo2 is much more extensive than in REF_Topo1 (Fig. 4a, b). This results from much colder surface air temperatures simulated over Beringia in K140_Topo2 (Fig. 2), which can be attributed to the development of a negative geopotential height anomaly allowing cold Arctic air to penetrate into this area, while at the same time precipitation does not change significantly between the two climate simulations (Colleoni and others, 2016b).

Niessen and others (2013) and Dove and others (2014) recently identified marine glaciogenic landforms at $\sim 1 \mathrm{~km}$ depth in the East Siberian Sea, and proposed that this area might have been covered by an ice cap that expanded over the emerged continental shelf, promoting the growth of an ice shelf in the Chukchi Sea. In both simulations, REF_Topo1 and REF_Topo2, an ice cap grows over Beringia, reaching thicknesses of up to $2500 \mathrm{~m}$ (Fig. 4a, b). This is due to the initial topography used in the climate simulations, in which this area emerges due to the sea-level drop. As a consequence of the simulated cold climate, a perennial snow cover accumulates over this emerged area (Colleoni and others, 2016b; their Fig. 8). In addition, the snow cover in this area is particularly thick, which further strengthens the snow albedo feedback. Therefore these conditions are favorable to the growth of an ice sheet in GRISLI. Due to a much larger extent, the total ice volume over Beringia and East Siberia is around twice as large in REF_Topo2 as in REF_Topo1 (23.8 m SLE vs 10.6 m SLE; Fig. 6c; Table 2). Colleoni and others (2016a) showed that this East Siberian perennial snow cover is a robust feature of the PGM climate compared with the LGM and is not climate model dependent.
Note that the northern part of Alaska remains ice free in both simulations. The reason for this is relatively warm air masses over Alaska (Fig. 2), which originate from the south and could not be blocked on their way north due to rather low simulated Cordillerian and Laurentide ice sheets (e.g. Löfverström and others, 2015).

\subsection{Impact of model parameters}

In the previous section, we presented ice-sheet simulations performed with model parameter values which we believe are standard. However, to increase the reliability of our results, a range of sensitivity experiments was performed. As described in Section 2.3, we branched all sensitivity experiments from REF_Topo1 and REF_Topo2 after $350 \mathrm{ka}$ of simulation. We assess the impact of each parameter in terms of ice volume, which is synthesized in Figure 6 and Table 2 for the Eurasian, Laurentide and Beringian/Siberian ice sheets for all sensitivity experiments using K140_Topo1 and K140_Topo2 climate forcing. In the following, we focus particularly on the parameters that lead to significant changes in ice volume, defined here as a deviation of $5 \%$ from the reference simulations.

Regarding climate correction parameters (group A), the model reacts particularly sensitively to changes in lapse rate and accumulation treatment. Using large lapse rates of $\lambda_{\text {Ann }}=8^{\circ} \mathrm{C} \mathrm{km}^{-1} ; \lambda_{\text {Jul }}=6.5^{\circ} \mathrm{C} \mathrm{km}^{-1}$ (experiment A3) almost leads to the complete retreat of the western Eurasian ice sheet, in particular under K140_Topo2 climate forcing due to the simulated warm temperature over this area (Fig. 2). Compared with the reference experiments, the Eurasian ice volume reduces by $5.5 \mathrm{~m} \mathrm{SLE}$ in case of K140_Topo1 forcing, and by $14.4 \mathrm{~m}$ SLE in case of K140_Topo2 forcing (Fig. 6; Table 2), which shows that this choice of lapse rates is not suitable to maintain an Eurasian ice sheet as large as reconstructed by Svendsen and others (2004) and Peyaud (2006). In contrast, the Laurentide ice sheet gains volume using high lapse rates, by 3.3 and $2.7 \mathrm{~m} \mathrm{SLE}$, 
Table 2. Final ice volume ( $m$ SLE) for the Eurasian, Laurentide and Beringian/Siberian ice sheets for all experiments

\begin{tabular}{|c|c|c|c|c|c|c|c|c|}
\hline \multirow[t]{2}{*}{ Run ID } & \multicolumn{2}{|c|}{ Eurasia } & \multicolumn{2}{|c|}{ North America } & \multicolumn{2}{|c|}{ Beringia/Siberia } & \multicolumn{2}{|c|}{ Globally } \\
\hline & Topo1 & Tоро2 & Topo1 & Topo2 & Topo1 & Topo2 & Topo1 & Topo2 \\
\hline REF & 52.0 & 50.3 & 83.6 & 59.2 & 10.6 & 23.8 & 162.2 & 149.7 \\
\hline A1 & 51.3 & 50.2 & 79.3 & 56.6 & 8.8 & 19.9 & 155.4 & 142.9 \\
\hline A2 & 52.7 & 51.2 & 85.4 & 61.2 & 11.3 & 23.9 & 165.5 & 152.5 \\
\hline A3 & 46.5 & 35.9 & 86.9 & 61.9 & 12.6 & 27.3 & 162.1 & 141.3 \\
\hline A5 & 53.1 & 51.1 & 83.6 & 57.8 & 10.0 & 22.2 & 162.7 & 147.6 \\
\hline A6 & 53.7 & 52.5 & 83.7 & 57.2 & 9.4 & 21.1 & 162.9 & 147.3 \\
\hline A7 & 50.9 & 47.0 & 81.6 & 57.9 & 10.2 & 22.9 & 158.7 & 144.0 \\
\hline A8 & 51.2 & 48.6 & 82.6 & 58.8 & 10.6 & 23.3 & 160.4 & 146.9 \\
\hline A9 & 51.9 & 49.1 & 83.0 & 59.3 & 10.5 & 26.4 & 161.4 & 151.0 \\
\hline A10 & 52.0 & 49.7 & 83.7 & 59.2 & 10.7 & 26.4 & 162.4 & 151.7 \\
\hline A11 & 48.5 & 45.1 & 76.0 & 52.8 & 8.2 & 18.8 & 148.5 & 132.6 \\
\hline B2 & 53.9 & 52.3 & 86.5 & 62.8 & 13.5 & 26.7 & 169.9 & 158.2 \\
\hline B3 & 54.2 & 52.6 & 86.7 & 62.4 & 14.9 & 27.8 & 171.8 & 159.1 \\
\hline B4 & 52.8 & 51.1 & 84.5 & 60.2 & 11.3 & 24.5 & 164.6 & 152.2 \\
\hline B5 & 51.6 & 48.3 & 83.5 & 58.8 & 10.2 & 22.5 & 161.3 & 145.9 \\
\hline B7 & 51.5 & 48.7 & 82.1 & 58.5 & 9.9 & 22.5 & 159.6 & 146.0 \\
\hline B8 & 52.2 & 50.3 & 84.0 & 59.5 & 10.5 & 24.1 & 162.7 & 150.3 \\
\hline C1 & 48.5 & 46.2 & 71.5 & 48.8 & 8.6 & 20.7 & 144.3 & 131.3 \\
\hline $\mathrm{C} 2$ & 52.3 & 50.1 & 83.7 & 59.4 & 10.7 & 25.1 & 162.7 & 150.8 \\
\hline $\mathrm{C} 3$ & 56.0 & 54.0 & 90.6 & 63.0 & 10.4 & 25.6 & 173.2 & 158.9 \\
\hline D1 & 52.3 & 49.9 & 83.6 & 59.2 & 10.6 & 23.3 & 162.5 & 148.7 \\
\hline D2 & 52.3 & 49.9 & 83.6 & 59.2 & 10.6 & 23.3 & 162.5 & 148.7 \\
\hline D3 & 52.0 & 49.9 & 83.6 & 59.2 & 10.4 & 26.0 & 162.0 & 151.6 \\
\hline D4 & 52.0 & 49.9 & 83.4 & 59.3 & 10.5 & 23.3 & 161.8 & 148.6 \\
\hline D5 & 52.0 & 50.1 & 83.5 & 59.1 & 10.5 & 25.5 & 161.9 & 150.8 \\
\hline D6 & 52.2 & 49.9 & 83.4 & 59.1 & 10.4 & 25.1 & 161.9 & 150.4 \\
\hline E1 & 52.2 & 50.0 & 83.5 & 59.2 & 10.8 & 23.5 & 162.5 & 149.1 \\
\hline E4 & 51.1 & 49.5 & 83.1 & 58.8 & 10.2 & 23.5 & 160.2 & 147.8 \\
\hline E5 & 52.3 & 49.9 & 83.8 & 59.1 & 10.7 & 26.3 & 162.8 & 151.5 \\
\hline
\end{tabular}

Global ice volume is also given, by accounting for $5 \mathrm{~m}$ SLE for Antarctica (Ivins and James, 2005) and $2 \mathrm{~m}$ SLE for other small ice caps, such as in New-Zealand and Patagonia (ICE-5 G LGM). Simulations that fall in the range of global sea-level reconstructions for the PGM (Rabineau and others, 2006) are indicated by bold font. Sensitivity experiments are grouped according to categories: Climate corrections (A), PDD parameters (B), Ice streams (C), Ice shelves (D) and Solid earth (E).

respectively, for K140_Topo1 and K140_Topo2 climate forcing. Increasing lapse rates leads to higher surface air temperature and thus higher ablation than in the reference experiments. This induces an increase in vertical heat diffusion, leading to a warmer ice-sheet base, which in turn causes higher sliding velocities. As a consequence of the warmer surface, accumulation is higher than in the reference experiments due to the precipitation correction parametrization adopted in the GRISLI model, based on Charbit and others (2002). The warmer base and the higher accumulation partly compensate each other, and lead to an opposite response of Eurasian and Laurentide ice sheets to a larger lapse rate value.

Using the simulated snowfall field instead of the total precipitation (experiment A11) strongly reduces the Eurasian and Laurentide ice volumes by 3.5 and $5.2 \mathrm{~m} \mathrm{SLE}$, respectively, compared with REF_Topo1 (Fig. 6; Table 2). A similar response occurs under K140_Topo2 climate forcing. This is because the simulated total precipitation is constituted of the liquid precipitation and the snowfall. Providing the snowfall field only to GRISLI reduces the amount of accumulation occurring over the ice sheets. When accounting for the total precipitation input, the runtime temperature correction resulting from changes in ice-sheet elevation can lead to cooler conditions, mostly occurring along the ice-sheet margins, where in the initial climate forcing, precipitation was only liquid.

Changes in PDD parameters (group B) have a moderate impact on the simulated ice volumes, as ablation is confined to the margins of the ice sheets (Fig. 5e, f). Compared with the reference experiment REF_Topo1, using higher melting rates for ice $\left(C_{\text {ice }}\right)$ and snow $\left(C_{\text {snow }}\right)$ (experiment B1) decreases the Eurasian and Laurentide ice volumes by 1.4 and $4 \mathrm{~m} \mathrm{SLE}$, respectively, relative to REF_Topo1 (Fig. 6; Table 2). Coherently, using lower melting rate coefficients (experiment B2) increases the Eurasian and Laurentide ice volumes by 1.9 and $2 \mathrm{~m} \mathrm{SLE}$, respectively, relative to REF_Topo1. Decreasing the standard deviation of surface air temperature, $\sigma$, to $3^{\circ} \mathrm{C}$ (experiment B3), leads to a reduction in ablation and therefore to an increase in Eurasian and Laurentide ice volume of $\sim 2.2 \mathrm{~m}$ SLE and $3.1 \mathrm{~m}$ SLE compared with REF_Topo1. Using K140_Topo2 climate forcing leads to similar results as using K140_Topo1 climate forcing.

The strongest model response occurs when perturbing ice streams related parameters (group C). Using lower thresholds for the sediment thickness and hydraulic head (note that both parameters are connected; Section 2.3), as done in experiment $\mathrm{C} 1$, leads to an expansion of the fast-flow areas (i.e. an expansion of areas treated with the SSA; Section 2.1) 
compared with the reference simulations. This increases basal velocities in areas treated with SIA only in the reference simulations. As a result, the ice sheets lose mass and become flatter than in the reference simulations. These changes in ice volume are more pronounced for the Laurentide ice sheet (reduction by $12.1 \mathrm{~m}$ SLE compared with REF_Topo1) than for the Eurasian ice sheet (reduction by $3.5 \mathrm{~m}$ SLE compared with REF_Topo1) (Fig. 6; Table 2). This is because in the reference simulations, the Laurentide ice sheet exhibits only a few ice streams compared with the Eurasian ice sheet (Fig. 5a, b). Consequently, the Laurentide ice sheet is more sensitive than the Eurasian ice sheet to an increase in the area treated with the SSA.

Using a larger basal drag coefficient $c_{\mathrm{f}}$ compared with the reference value, as is done in experiment $\mathrm{C} 3$, substantially reduces the velocities at the base of the ice sheet in icestream areas, which are located mostly where the sediment layer is thick (Fig. 3a). Compared with REF_Topo1, the Eurasian and Laurentide ice sheets consequently thicken and gain mass (increase by 4 and $7 \mathrm{~m} \mathrm{SLE}$, respectively). Similarly, using K140_Topo2 climate forcing the Eurasian and Laurentide ice volume increases by 3.7 and $3.8 \mathrm{~m} \mathrm{SLE}$, respectively, compared with REF_Topo2.

The model is relatively insensitive to changes in ice-shelf geometry related parameters (group D) or changes in solid earth parameters (group E). In our simulations, most of the ice sheets are grounded (not shown; see Colleoni and others, 2014). Therefore, the overall simulated ice volume is not particularly sensitive to changes in the calving front thickness and basal melt rate below the ice shelves (Fig. 6; Table 2). Changes in GHF have a relatively small impact on Eurasian ice volume, as large parts of the ice-sheet base are already at the pressure melting point due to relatively warm climate and the large thickness of the ice sheets (Fig. 5c, d). Similarly, the model results are insensitive to changes in parameters related to isostasy, as we perform steady-state sensitivity experiments that are branched from an already spun-up ice-sheet topography, already in isostatic equilibrium.

Over East Siberia, the ice cap exhibits a similar dynamical behavior to changes in model parameters as the Laurentide and the Eurasian ice sheets (Fig. 6c). However, the sensitivity of the East Siberian ice cap to changes in model parameters is larger compared with the responses of the Laurentide and Eurasian ice sheets. This is because the ice cap is smaller than those ice sheets and is therefore more sensitive to changes in air surface temperature and precipitation than the two larger ice sheets (group A and B). Consequently, while in the case of the Laurentide and Eurasian ice sheets the upper and lower bounds in ice volume are given by simulations of group C, i.e. basal drag and ice stream area related simulations, the upper and lower bounds are given by group A, i.e. climate forcing related simulations. In addition, the East Siberian ice cap is also sensitive to changes in iceshelf basal melting and calving criteria (group D) under K140_Topo2 climate conditions because some ice shelves develop in this area (not shown), which is not the case under K140_Topo1 climate conditions. Because this ice cap develops from an ice-free topography, it is in general more sensitive to isostasy, which induces a negative elevation feedback on the surface air temperature and precipitation correction during the simulation, and to GHF variations (group E). The maximum simulated ice volume of the East Siberian ice cap amounts to $14.9 \mathrm{~m}$ SLE and
$27.8 \mathrm{~m}$ SLE in experiment B3, whereas the minimum amounts to $8.2 \mathrm{~m} \mathrm{SLE}$ and $18.8 \mathrm{~m} \mathrm{SLE}$ in experiment $\mathrm{A} 11$ under K140_Topo1 and K140_Topo2 climate forcing, respectively.

\section{DISCUSSION}

We performed an ensemble of steady-state ice-sheet experiments simulating the MIS 6 glacial maximum Northern Hemisphere ice-sheet topography, forced by two PGM climate simulations, and based on two different Northern Hemisphere PGM ice-sheet topographies (Topo1 and Topo2; Colleoni and others, 2016b). To understand whether those ice-sheet topographies were viable or not in an ice-sheet model, the parameter space of GRISLI was systematically tested by means of univariate sensitivity experiments. The simulations described in the previous sections show that under K140_Topo1 climate conditions, Topo1 is viable; however, the dimension of the Laurentide ice sheet is particularly large, which could lead to overestimated volume and extent, even in the framework of the penultimate glaciation. Under K140_ Topo2 climate conditions, which are warmer than the K140_Topo1 conditions, the dimensions of the Laurentide and Eurasian ice sheets seem more reasonable. Also, a large ice cap develops over East Siberia, which is not in contradiction with the geological evidence. In the following discussion, we put our results in the context of global PGM ice volume. Then, we discuss the impact of the initialization method and the effect of steady-state simulations on the ice-sheets geometry.

\subsection{Global PGM ice volume}

Reconstructing the global ice topography is a difficult exercise when only few data are available to constrain the individual ice sheets for a given time period. In Colleoni and others (2016b), to account for the uncertainty on ice topography, two different Northern Hemisphere ice-sheet topographies were prescribed (Section 2.2). Both topographies include the PGM Eurasian ice sheet from Peyaud (2006) and the LGM Greenland and Antarctic ice sheets. However, they differ over North America where the LGM Laurentide ice topography was imposed in Topo1, while a substantially smaller Laurentide ice topography corresponding to $13 \mathrm{ka}$ BP was prescribed in Topo2. The distinction in the Laurentide ice-sheet topographies derives from the fact that no geological evidence for a larger glaciation than the LGM over this area has been found so far (Dyke and others, 2002). This implies that previous glaciations over North America could have been smaller than or no larger than the LGM Laurentide ice sheet. The reader may refer to Colleoni and others (2014) and Colleoni and others (2016b) for a more detailed discussion about the Laurentide topography. In addition, Colleoni and others (2016b) assume that Antarctica and Greenland during MIS 6 glacial maximum were not substantially different than during the LGM, which is supported by De Boer and others (2014) for Antarctica.

Both initial global ice-sheet topographies, Topo1 and Topo2, lead to an ice volume of $167 \mathrm{~m}$ SLE when accounting for the LGM Laurentide ice sheet and of $123 \mathrm{~m}$ SLE when reducing the Laurentide ice volume (Table 3). According to past sea-level data, the MIS 6 glacial maximum sea-level drop ranges between $92 \mathrm{~m}$ and $\sim 150 \mathrm{~m}$ (Rabineau and 
Table 3. Ice volume comparison of various PGM reconstructions departing from present-day ice-sheet volume

\begin{tabular}{|c|c|c|c|c|c|c|c|}
\hline Reconstruction & $\begin{array}{l}\text { Total } \\
\mathrm{m} \mathrm{SLE}\end{array}$ & $\begin{array}{l}\text { Laurentide } \\
\text { m SLE }\end{array}$ & $\begin{array}{l}\text { Eurasia } \\
\mathrm{m} \mathrm{SLE}\end{array}$ & $\begin{array}{c}\text { Beringia/East Siberia } \\
\mathrm{m} \mathrm{SLE}\end{array}$ & $\begin{array}{l}\text { AlS } \\
\mathrm{m} \mathrm{SLE}\end{array}$ & $\begin{array}{c}\text { GIS } \\
\mathrm{m} \mathrm{SLE}\end{array}$ & $\begin{array}{l}\text { Other } \\
\mathrm{m} \text { SLE }\end{array}$ \\
\hline ICE-5G & 107 & 74 & 17 & - & 5 & 9 & 2 \\
\hline K140_Topo1 & 167 & 80 & 71 & - & 5 & 9 & 2 \\
\hline K140_Торо2 & 123 & 36 & 71 & - & 5 & 9 & 2 \\
\hline REF_Topo1 (GRISLI) & 163 & 84 & 52 & 11 & 5 & 9 & 2 \\
\hline REF_Topo2 (GRISLI) & 149 & 59 & 50 & 24 & 5 & 9 & 2 \\
\hline
\end{tabular}

K140_Topo1 corresponds to the climate simulation from Colleoni and others (2016b) in which the Late Saalian ice topography from Peyaud (2006) and the ICE5G Laurentide ice sheet from Peltier (2004) were prescribed, whereas in K140_Topo2 a smaller Laurentide ice sheet (13 ka, Peltier, 2004) was prescribed; REF_Topo1 and REF_Topo2 (GRISLI) take into account the modeled reference Northern Hemisphere ice sheets obtained in the present study using K140_Topo1 and K140_Topo2 climate forcing, respectively. For comparison, ICE-5 G ice-sheet volume is also shown. AIS stands for Antarctic ice sheet (estimated ice volume from Ivins (2005)), GIS for Greenland ice sheet (from ICE-5 G LGM model) and Other corresponds to the small ice caps, such as over NewZealand and Patagonia (ICE-5G LGM).

others, 2006). This means that the global ice-sheet topography prescribed in K140_Topo1 is out of the range of past observations. On the contrary, the ice-sheet topography prescribed in K140_Topo2 stays in the range of the observations. If we now account for the Northern Hemisphere ice volumes from the two control simulations carried out in the present study, it leads to a simulated global volume of $162.2 \mathrm{~m} \mathrm{SLE}$ in the case of Topo1 and $149.7 \mathrm{~m} \mathrm{SLE}$ in the case of Topo2 (Table 3). Only REF_Topo2 is in the range of past sea-level reconstructions. Based on this comparison, most sensitivity experiments using K140_Topo1 forcing fall out of the range of global sea-level reconstructions, except for experiments A11 and C1 (Fig. 7; Table 2). Conversely, several experiments using K140_Topo2 forcing match the sea-level reconstruction. In the case of K140_Topo2 forcing the lower bound in Northern Hemisphere ice volume reaches 124.3 m SLE in experiment $\mathrm{C} 1$, which, accounting for the other ice sheets, would lead to a global ice volume of $131.3 \mathrm{~m} \mathrm{SLE}$, whereas the upper bound in Northern Hemisphere ice volume reaches $\sim 152 \mathrm{~m}$ SLE in experiments B3 and C1. Figure 8 shows three examples of final ice-sheet topographies that match the sea-level reconstruction.

Our simulations cannot directly provide clues to reconstruct a global ice topography because we forced GRISLI with two simulated climates, in which idealized PGM ice topographies were prescribed. However, it suggests that a relatively large Eurasian ice sheet $(\sim 50 \mathrm{~m} \mathrm{SLE})$, but smaller than that suggested by Peyaud (2006), in combination with a relatively small Laurentide ice sheet ( $\sim 60 \mathrm{~m} \mathrm{SLE})$ compared with LGM conditions as obtained in our Topo2 simulations, is reasonable in terms of global water budget. Moreover, as described by Colleoni and others (2016b), a small Laurentide ice sheet is necessary to generate a shift in planetary waves sufficient to induce a cooling over East Siberia and Alaska in order to match with both sea surface temperature proxies and ice-sheet dynamics evidence.

\subsection{Initialization of simulations}

In our study, the MIS 6 Eurasian ice sheet equilibrates at a total ice volume of $52 \mathrm{~m}$ SLE for REF_Topo1 and $50.3 \mathrm{~m}$ SLE for REF_Topo2. In the case of REF_Topo1, this is $26 \%$ less than in the original reconstruction from Peyaud (2006). There is no direct evidence of the PGM Eurasian ice volume, and the only two reconstructions that existed before the present study are those of Peyaud (2006) and Lambeck and others (2006). The latter study corresponds to a simulated ice volume of $\sim 60 \mathrm{~m} \mathrm{SLE}$, which is close to what we obtain in the present study. Lambeck and others (2006) used an idealized ice-sheet model in combination
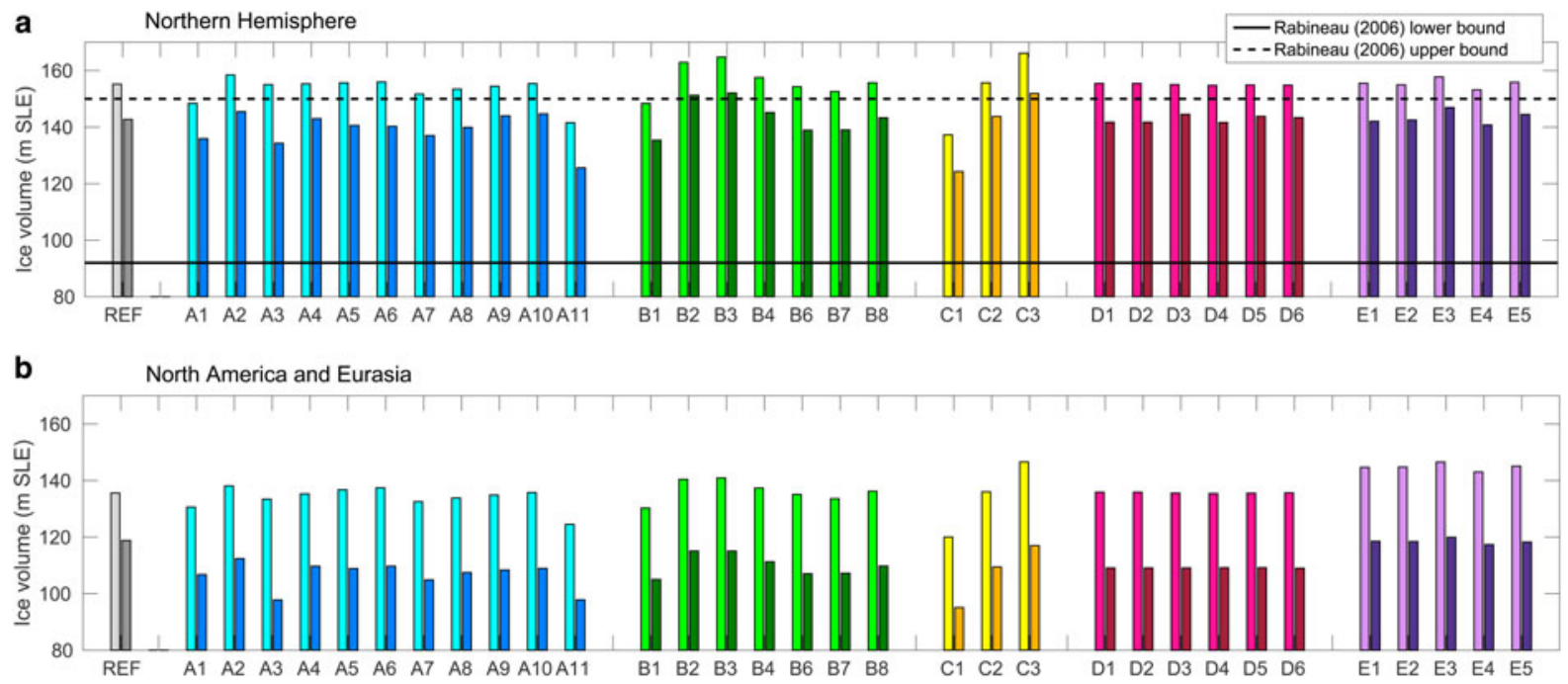

Fig. 7. Ice volume (m SLE) of the Northern Hemisphere (a) and North American + Eurasian ice sheets (excluding the Siberian ice cap) (b) for experiments using K140_Topo1 forcing (light colors) and K140_Topo2 forcing (dark colors) at the end of the simulations. Black solid and dashed lines denote the lower and upper limits, respectively, of global sea-level reconstructions for MIS 6 by Rabineau and others (2006). 


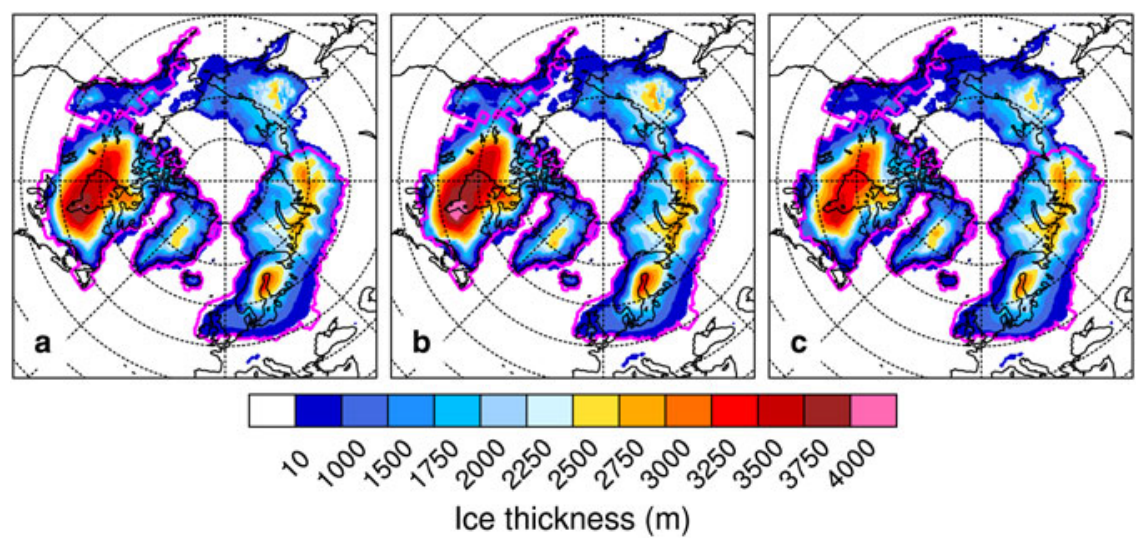

Fig. 8. Simulated final ice thickness for sensitivity experiments A11 (a), B1 (b) and C1 (c) using K140_Topo2 climate forcing. The magenta outline indicates the extent of the initial ice sheets prescribed Topo2 (Fig. 1b).

with a post-glacial rebound model to reconstruct the LateSaalian-Weichselian evolution of the Eurasian ice sheet. However, the fact that we use an ice-sheet model forced by coupled climate simulations of the PGM is a clear improvement with respect to the works by Peyaud (2006) and Lambeck and others (2006). For the PGM Laurentide ice sheet however, no estimates of ice volume exist. Nonetheless given the large ice volumes simulated in the present study, there are some aspects related to the initialization of our simulations and the assumption of steady state that need to be considered.

A continental-size ice sheet is characterized by a longterm memory of climate conditions, which affects the thermo-mechanical response on a long time-scale due to diffusion and advection of heat from the ice-sheet surface to the base, linked with mechanical deformation within the ice sheet itself. As a consequence, performing a realistic simulation of the ice-sheet evolution during a period of time requires knowledge of both the past and the contemporaneous climate conditions. This fact underlines the need to properly spin-up the ice-sheet model to obtain a realistic representation of the vertical temperature distribution within the modeled ice sheet.

To initialize the thermodynamical state of an ice sheet, two methods are commonly used, namely transient simulations driven by paleoclimate reconstructions of temperature and precipitation through time, or alternatively steady-state simulations forced by simulated climate conditions at a given time (Rogozhina and others, 2011; and references therein). In addition, when starting a steady-state simulation, it is possible to either use a prescribed ice-sheet topography or to start from an ice-free topography (relaxed from isostasy). Rogozhina and others (2011) show that starting from an icecovered topography shortens the spin-up time required to bring temperatures and velocities to equilibrium. However, glacial climate forcing bears low precipitation rates, which implies that simulations have to be longer before reaching steady state, thus leading to an underestimation of final ice volume.

In this study, we initialized our simulations starting from an ice-covered topography and ran those experiments for $450 \mathrm{ka}$. To understand what could have been the impact of initializing from an ice-free topography, we carried out an additional experiment starting from the present-day ice-free topography and forced by K140_Topo1 climate. Both experiments, i.e. starting from an ice-sheet topography and from an ice-free topography reach equilibrium after $\sim 100 \mathrm{ka}$ and the final ice-sheet extent and volume is similar (not shown). However, compared with the initial Eurasian ice volume from Peyaud (2006), the ice volume is $\sim 18 \mathrm{~m}$ SLE smaller and is closer to the Lambeck and others (2006) reconstruction.

In the case of transient simulations, precipitation before reaching the glacial maximum could potentially be larger because of warmer climate conditions. In this case, ablation that would occur because of high temperatures would be balanced by large precipitation rates and would not necessarily imply a larger or lower ice volume. Colleoni (2009) showed that under warmer climate conditions, i.e. $150 \mathrm{ka}$ $\mathrm{BP}$, the surface mass balance of the PGM Eurasian ice sheet would still be positive and not much lower than during the full PGM. As stressed by Rogozhina and others (2011), running a long simulation prescribing very low precipitation from the beginning might lead to a smaller ice volume than running it transiently for a shorter time period but starting from interglacial wet climate conditions and finishing with glacial dry climate conditions.

\section{CONCLUSIONS}

The overall aim of this study was to investigate the geometry of the Northern Hemisphere ice sheets during the PGM ( 140 ka BP). Our results show that:

When using a climate forcing accounting for a large Laurentide ice sheet (Topo1), the Eurasian ice-sheet volume decreases by $\sim 20 \mathrm{~m}$ SLE from the reconstruction of Peyaud (2006), whereas the Laurentide ice sheet does not change significantly. Prescribing a smaller Laurentide ice sheet (Topo2) in the climate simulations reduces both the Laurentide and the Eurasian ice volume by $\sim 20 \mathrm{~m}$ SLE compared with the initial prescribed topography, due to simulated warmer climate conditions.

The simulated Eurasian ice volume appears to be relatively insensitive to the changes induced by the atmospheric circulation when lowering the Laurentide ice-sheet elevation, whereas under the warmest simulated PGM climate conditions the Laurentide ice sheet remains small in the ice-sheet simulations. This means that once the Eurasian ice sheet has reached a significant dimension, it limits the growth of the Laurentide ice sheet by shifting the planetary waves and inducing local changes in temperatures and 
precipitations. This is supported by the findings from Beghin and others (2015) and Liakka and others (2015).

In both simulations, an ice sheet develops over Beringia and East Siberia, which is even more extensive when using K140_Topo2. This is supported by evidence recently found on the Arctic ocean floor (Niessen and others, 2013; Dove and others, 2014). This East Siberian ice cap is a distinctive feature of the penultimate glaciation because the evidence also indicates that this area remained mostly ice free during the LGM.

Finally, a comparison with proxies such as ice rafted debris in the North Atlantic and North Pacific suggests that experiments using climate forcing which accounts for a small Laurentide ice sheet are more realistic than when prescribing a large Laurentide ice sheet in the climate model. Furthermore, we find that Topo2 ice-sheet experiments are in better agreement with the global water budget for this time period.

In order to better constrain the PGM ice volume, it is necessary to perform a transient coupled ice-sheet-climate simulation. Since there is little evidence of the PGM glaciation remains, it will be highly difficult to validate the evolution of the ice-sheet topography over the penultimate glacial cycle. However, following the approach by Colleoni and others (2016b), testing different ice-sheet combinations in a coupled climate model and comparing the simulated climate dynamics with multi-proxy compilations, should help to reduce the number of viable ice-sheet topographies for the PGM.

\section{ACKNOWLEDGEMENTS}

Financial support for this study was provided by the Swedish Nuclear Fuel and Waste Management Company (SKB) and by the Finnish Waste Management Company Posiva. We acknowledge the numerical support of CMCC Foundation. We thank Catherine Ritz for providing the GRISLI code and Vincent Peyaud for providing the initial ice topography used in this study. We acknowledge Nina Kirchner, Mike Thorne, Allan Hedin and Patrick Applegate for helpful discussions.

\section{REFERENCES}

Abe-Ouchi A, Segawa T and Saito F (2007) Climatic conditions for modelling the Northern Hemisphere ice sheets throughout the ice age cycle. Clim. Past, 3, 423-438 (doi: 10.5194/cp-3-4232007)

Abe-Ouchi A and 9 others (2015) Ice-sheet configuration in the CMIP5/PMIP3 Last Glacial Maximum experiments. Geoscie. Model Dev., 8, 3621-3637 (doi: 10.5194/gmd-8-3621-2015)

Abreu L, Shackleton N, Schonfeld J, Hall M and Chapman M (2003) Millennial-scale oceanic climate variability off the Western Iberian margin during the last two glacial periods. Mar. Geol., 196, 1-20 (doi: 10.1016/S0025-3227(03)00046-X)

Alvarez-Solas J and 8 others (2011) Heinrich event 1: an example of dynamical ice-sheet reaction to oceanic changes. Clim. Past, 7 1297-1306 (doi: 10.5194/cp-7-1297-2011)

Astakhov VI (2004) Middle Pleistocene glaciations of the Russian North. Quat. Sci. Rev., 23, 1229-1271 (doi: 10.1016/j.quascirev. 2003.12.011)

Barr ID and Solomina O (2014) Pleistocene and Holocene glacier fluctuations upon the Kamchatka Peninsula. Global Planet. Change, 113, 110-120 (doi: 10.1016/j.gloplacha.2013.08.005)

Beghin P, Charbit S, Dumas C, Kageyama M and Ritz C (2015) How might the North American ice sheet influence the northwestern
Eurasian climate?. Clim. Past, 11, 1467-1490 (doi: 10.5194/cp11-1467-2015)

Berger A and Loutre MF (1991) Insolation values for the climate of the last 10 millions years. Quat. Sci. Rev., 10, 297-317 (doi: 10.1016/0277-3791(91)90033-Q)

Bonelli S and 6 others (2009) Investigating the evolution of major Northern Hemisphere ice sheets during the last glacial-interglacial cycle. Clim. Past, 5, 329-345 (doi: 10.5194/cp-5-3292009)

Brady EC, Otto-Bliesner BL, Kay JE and Rosenbloom N (2013) Sensitivity to Glacial Forcing in the CCSM4. J. Clim., 26, 19011925 (doi: 10.1175/JCLI-D-11-00416.1)

Charbit S, Ritz C and Ramstein G (2002) Simulations of Northern Hemisphere ice-sheet retreat: sensitivity to physical mechanisms involved during the Last Deglaciation. Quat. Sci. Rev., 21, 243265 (doi: 10.1016/S0277-3791(01)00093-2)

Charbit S, Dumas C, Kageyama M, Roche DM and Ritz C (2013) Influence of ablation-related processes in the build-up of simulated Northern Hemisphere ice sheets during the last glacial cycle. Cryosphere, 7, 681698 (doi: 10.5194/tc-7-681-2013)

Clark PU, Licciardi JM, MacAyeal DR and Jenson JW (1996) Numerical reconstruction of a soft-bedded laurentide ice sheet during the last glacial maximum. Geology, 24(8), 679-682 (doi: 10.1130/0091-7613(1996)024<0679:NROASB > 2.3.CO;2)

Colleoni F (2009) On the Late Saaliab glaciation (160-140 ka) - a climate modeling study. Ph.D. thesis, Laboratoire de Glaciologie et de Géophysique de I'Environnement, Université Grenoble I

Colleoni F, Wekerle C and Masina S (2014) Long-term safety of a planned geological repository for spent nuclear fuel in forsmark - estimate of maximum ice sheet thicknesses. Swedish Nuclear Fuel and Waste Management Co, Stockholm, Sweden, 1-96

Colleoni F, Kirchner N, Niessen F, Quiquet A and Liakka J (2016a) An east Siberian ice shelf during the late pleistocene glaciations: numerical reconstructions. Quat. Sci. Rev., in press (doi: doi:10.1016/j.quascirev.2015.12.023)

Colleoni F, Wekerle C, Näslund JO, Brandefelt J and Masina S (2016b) Constrain on the MIS 6 glacial maximum ice topography ( 140 kyrs BP). Quat. Sci. Rev., 137, 97-112 (doi: 10.1016/j. quascirev.2016.01.024)

De Boer B, Lourens LJ and Van De Wal RS (2014) Persistent 400,000-year variability of Antarctic ice volume and the carbon cycle is revealed throughout the Plio-Pleistocene. Nat. Commun., 5, 1-8 (doi: 10.1038/ncomms3999)

Dove D, Polyak L and Coakley B (2014) Widespread, multi-source glacial erosion on the Chukchi margin, Arctic Ocean. Quat. Sci Rev., 92, 112-122 (doi: 10.1016/j.quascirev.2013.07.016)

Dyke AS and 6 others (2002) The laurentide and Innuitian ice sheets during the last glacial maximum. Quat. Sci. Rev., 21, 9-31 (doi: 10.1016/S0277-3791(01)00095-6)

Gent PR and 12 others (2011) The community climate system model version 4. J. Clim., 24, 4973-4991 (doi: 10.1175/2011 JCLI4083.1)

Greve R (2005) Relation of measured basal temperatures and the spatial distribution of the geothermal heat flux for the Greenland ice sheet. Ann. Glaciol., 42(424-432) (doi: 10.3189/ $172756405781812510)$

Hellmer $\mathrm{HH}$, Kauker F, Timmermann R, Determann J and Rae J (2012) Twenty-first-century warming of a large Antarctic iceshelf cavity by a redirected coastal current. Nature, 485, 225228 (doi: 10.1038/nature11064)

Hiscott R, Aksu A, Mudie P and Parsons D (2001) A 340,000 year record of ice rafting, palaeoclimatic fluctuations, and shelf-crossing glacial advances in the southwestern Labrador Sea. Global Planet. Change, 28, 227-240 (doi: 10.1016/S0921-8181(00) 00075-8)

Hutter K (1983) Theoretical glaciology: material science of ice and the mechanics of glaciers and ice sheets. Reidel Publishing Company, Dordrecht, The Netherlands, ISBN 978-90-2771473-2 
Ivins ER and James TS (2005) Antarctic glacial isostatic adjustment: a new assessment. Antarct. Sci., 17(04), 541-553 (doi: 10.1017/ S0954102005002968)

Kleman J and Hattestrand C (1999) Frozen-bed Fennoscandian and Laurentide ice sheets during the last glacial maximum. Nature, 402, 63-66 (doi: 10.1038/47005)

Kleman J, Fastook J, Ebert K, Nilsson J and Caballero R (2013) PreLGM Northern Hemisphere paleo-ice sheet topography. Clim. Past, 9(3), 2557-2587 (doi: 10.5194/cp-9-2365-2013)

Krinner $\mathrm{G}$ and 5 others (2004) Enhanced ice sheet growth in Eurasia owing to adjacent ice-dammed lakes. Nature, 427, 429-432 (doi: 10.1038/nature02233)

Lambeck K and 5 others (2006) Constraints on the Late Saalian to early Middle Weichselian ice sheet of Eurasia from field data and rebound modelling. Boreas, 35, 539-575 (doi: 10.1080/ 03009480600781875)

Laske G and Masters G (1997) A global digital map of sediment thickness. EOS Trans. AGU, 78, F483

Le Meur E and Huybrechts P (1996) A comparison of different ways of dealing with isostasy: examples from modeling the Antarctic ice sheet during the last glacial cycle. Ann. Glaciol., 23, 309-317

Liakka J, Löfverström M and Colleoni F (2015) The impact of the North American ice sheet on the evolution of the Eurasian ice sheet during the last glacial cycle. Clim. Past Discuss., 11, 5203-5241 (doi: 10.5194/cpd-11-5203-2015)

Löfverström M, Liakka J and Kleman J (2015) The North American Cordillera-An impediment to growing the continent-wide Laurentide ice sheet. J. Clim., 28(23), 9433-9450 (doi: 10.1175/ JCLI-D-15-0044.1)

MacAyeal D (1989) Large-scale ice flow over a viscous basal sediment: theory and application to ice stream B, Antarctica. J. Geophys. Res., 94, 4071-4087 (doi: 10.1029/JB094i B04p04071)

Marshall S, James T, and Clarke G (2002) North American ice sheet reconstructions at the last glacial maximum. Quat. Sci. Rev., 21, 175-192 (doi: 10.1016/S0277-3791(01)00089-0)

Masson-Delmotte $V$ and 16 others (2010) EPICA Dome $C$ record of glacial and interglacial intensities. Quat. Sci. Rev., 29(1-2), 113128 (doi: 10.1016/j.quascirev.2009.09.030)

Naafs BDA, Hefter J and Stein R (2013) Millennial-scale ice rafting events and Hudson Strait Heinrich(-like) Events during the late Pliocene and Pleistocene: a review. Quat. Sci. Rev., 80, 1-28 (doi: 10.1016/j.quascirev.2013.08.014)

Näslund JO, Jansson P, Fastook JL, Johnson J and Anderson L (2005) Detailed spatially distributed geothermal heat-flow data for modeling of basal temperatures and meltwater production beneath the Fennoscandian ice sheet. Ann. Glaciol., 40, 95-101 (doi: $10.3189 / 172756405781813582)$

Niessen F and 9 others (2013) Repeated Pleistocene glaciation of the East Siberian continental margin. Nat. Geosci., 6(10), 842-846 (doi: 10.1038/ngeo1904)

Nürnberg D, Dethleff D, Tiedemann R, Kaiser A and Gorbarenko SA (2011) Okhotsk Sea ice coverage and Kamchatka glaciation over the last $350 \mathrm{ka}$ Evidence from ice-rafted debris and planktonic 18O. Palaeogeogr. Palaeoclimatol. Palaeoecol., 310, 191-205 (doi: 10.1016/j.palaeo.2011.07.011)

Obrochta S and 6 others (2014) Climate variability and ice-sheet dynamics during the last three glaciations. Earth Planet. Sci. Lett., 406, 198-212 (doi: 10.1016/j.epsl.2014.09.004)

Pausata F, Li C, Wettstein J, Kageyama M and Nisancioglu K (2011) The key role of topography in altering North Atlantic atmospheric circulation during the last glacial period. Clim. Past, 7(4), 10891101 (doi: 10.5194/cp-7-1089-2011)

Peltier W (2004) Global glacial isostasy and the surface of the iceage Earth: The ICE-5 G (VM2) Model and GRACE. Annu. Rev.
Earth Planet. Sci., 32, 111-149 (doi: 10.1146/annurev. earth.32.082503.144359)

Petit J and 18 others (1999) Climate and atmospheric history of the past 420,000 years from the Vostok ice core, Antarctica. Nature, 399, 429-436 (doi: 10.1038/20859)

Peyaud V (2006) Role of the Ice Sheet Dynamics in major climate changes. Ph.D. thesis, Laboratoire de Glaciologie et de Géophysique de l'Environnement, Université Grenoble I

Peyaud V, Ritz C and Krinner G (2007) Modelling the early Weichselian Eurasian ice sheets: role of ice shelves and influence of ice-dammed lakes. Clim. Past, 3, 375-386 (doi: 10.5194/cp-3375-2007)

Pfeffer WT, Meier MF and Illangasekare TH (1991) Retention of Greenland runoff by refreezing: implications for projected future sea level change. J. Geophy. Res., 96(C12), 2211722124 (doi: 10.1029/91JC02502)

Quiquet A and 9 others (2012) Sensitivity of a Greenland ice sheet model to atmospheric forcing fields. Cryosphere, 6, 999-1018 (doi: 10.5194/tc-6-999-2012)

Rabineau M and 5 others (2006) Paleo sea levels reconsidered from direct observation of paleoshore-line position during glacial maxima (for the last 500,000 yr). Earth Planet. Sci. Lett., 252, 119-137 (doi: 10.1016/j.epsl.2006.09.033)

Reeh N (1991) Parameterization of melt rate and surface temperature on the Greenland ice sheet. Polarforschung, 59(3), 113128

Ritz C, Rommelaere V and Dumas C (2001) Modeling the evolution of Antarctic ice sheet over the last 420,000 years: Implications for altitude changes in the Vostok region. J. Ceophy. Res., 106(D23), 31,943-31,964 (doi: 10.1029/2001JD900232)

Rogozhina I, Martinec Z, Hagedoorn J, Thomas M and Fleming K (2011) On the long-term memory of the Greenland Ice Sheet. J. Geophys. Res-Earth, 116(F01011), 1-16 (doi: 10.1029/ 2010JF001787)

Rutt IC, Hagdorn M, Hulton NRJ and Payne AJ (2009) The glimmer community ice sheet model. J. Geophys. Res., 114(F02004), 122 (doi: 10.1029/2008JF001015)

Shapiro N and Ritzwoller M (2004) Inferring surface heat flux distributions guided by a global seismic model: particular application to Antarctica. Earth Planet. Sci. Lett., 223, 213-224 (doi: 10.1016/j.epsl.2004.04.011)

Spahni R and 9 others (2005) Atmospheric methane and nitrous oxide of the late Pleistocene from Antarctic ice cores. Science, 310(5752), 1317-1321 (doi: 10.1126/science.1120132)

St John KEK and Krissek LA (1999) Regional patterns of Pleistoceneic e-rafted debris ux in the North Pacific. Paleoceanography, 14(5), 653-662 (doi: 10.1029/1999PA900030)

Svendsen J and others (2004) Late Quaternary ice sheet history of Northern Eurasia. Quat. Sci. Rev., 23, 1229-1271 (doi: 10.1016/j.quascirev.2003.12.008)

Tarasov L and Peltier WR (1999) Impact of thermomechanical ice sheet coupling on a model of the $100 \mathrm{kyr}$ ice age cycle. J. Geophy. Res., 104(D8), 9517-9545 (doi: 10.1029/1998) D200120)

Turcotte DL and Schubert G (2002) Geodynamics. Cambridge Univ. Press, New York, ISBN 9780521186230

Ullman DJ, LeGrande AN, Carlson AE, Anslow FS and Licciardi JM (2014) Assessing the impact of laurentide ice sheet topography on glacial climate. Clim. Past, 10, 487-507 (doi: 10.5194/cp10-487-2014)

Vizcaino M, Mikolajewicz U, Jungclaus J and Schurgers G (2010) Climate modification by future ice sheet changes and consequences for ice sheet mass balance. Clim. Dyn., 34, 301-324 (doi: 10.1007/s00382-009-0591-y) 